Georgia State University

ScholarWorks @ Georgia State University

\title{
The Impact of Tax and Expenditure Policies on Income Distribution: Evidence from a Large Panel of Countries
}

Jorge Martinez-Vazquez

Georgia State University, jorgemartinez@gsu.edu

Blanca Moreno-Dodson

The World Bank

Violeta Vulovic

vvulovic@worldbank.org

Follow this and additional works at: https://scholarworks.gsu.edu/icepp

Part of the Economics Commons

\section{Recommended Citation}

Martinez-Vazquez, Jorge; Moreno-Dodson, Blanca; and Vulovic, Violeta, "The Impact of Tax and Expenditure Policies on Income Distribution: Evidence from a Large Panel of Countries" (2012). ICEPP Working Papers. 77.

https://scholarworks.gsu.edu/icepp/77

This Working Paper is brought to you for free and open access by the International Center for Public Policy at ScholarWorks @ Georgia State University. It has been accepted for inclusion in ICEPP Working Papers by an authorized administrator of ScholarWorks @ Georgia State University. For more information, please contact scholarworks@gsu.edu. 
INTERNATIONAL CENTER FOR PUBLIC POLICY
International Center for Public Policy Working Paper 12-25

April 2012

The Impact of Tax and Expenditure Policies on Income Distribution: Evidence from a Large Panel of Countries

Jorge Martinez-Vazquez Blanca Moreno-Dodson Violeta Vulovic 

International Center for Public Policy

Working Paper 12-25

\title{
The Impact of Tax and Expenditure Policies on Income Distribution: Evidence from a Large Panel of Countries
}

\author{
Jorge Martinez-Vazquez \\ Blanca Moreno-Dodson \\ Violeta Vulovic
}

\section{April 2012}

International Center for Public Policy

Andrew Young School of Policy Studies

Georgia State University

Atlanta, Georgia 30303

United States of America

Phone: (404) 651-1144

Fax: (404) 651-4449

Email: hseraphin@gsu.edu

Internet: http://aysps.gsu.edu/isp/index.html

Copyright 2006, the Andrew Young School of Policy Studies, Georgia State University. No part of the material protected by this copyright notice may be reproduced or utilized in any form or by any means without prior written permission from the copyright owner. 


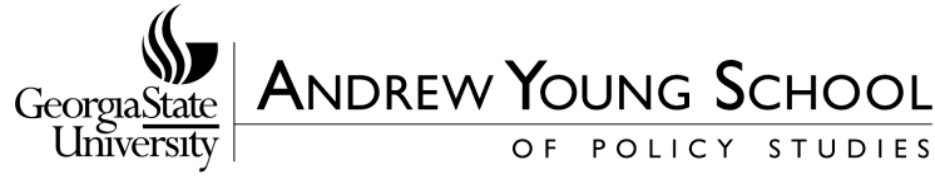

\section{International Center for Public Policy Andrew Young School of Policy Studies}

The Andrew Young School of Policy Studies was established at Georgia State University with the objective of promoting excellence in the design, implementation, and evaluation of public policy. In addition to two academic departments (economics and public administration), the Andrew Young School houses seven leading research centers and policy programs, including the International Center for Public Policy.

The mission of the International Center for Public Policy is to provide academic and professional training, applied research, and technical assistance in support of sound public policy and sustainable economic growth in developing and transitional economies.

The International Center for Public Policy at the Andrew Young School of Policy Studies is recognized worldwide for its efforts in support of economic and public policy reforms through technical assistance and training around the world. This reputation has been built serving a diverse client base, including the World Bank, the U.S. Agency for International Development (USAID), the United Nations Development Programme (UNDP), finance ministries, government organizations, legislative bodies and private sector institutions.

The success of the International Center for Public Policy reflects the breadth and depth of the in-house technical expertise that the International Center for Public Policy can draw upon. The Andrew Young School's faculty are leading experts in economics and public policy and have authored books, published in major academic and technical journals, and have extensive experience in designing and implementing technical assistance and training programs. Andrew Young School faculty have been active in policy reform in over 40 countries around the world. Our technical assistance strategy is not to merely provide technical prescriptions for policy reform, but to engage in a collaborative effort with the host government and donor agency to identify and analyze the issues at hand, arrive at policy solutions and implement reforms.

The International Center for Public Policy specializes in four broad policy areas:

- Fiscal policy, including tax reforms, public expenditure reviews, tax administration reform

- Fiscal decentralization, including fiscal decentralization reforms, design of intergovernmental transfer systems, urban government finance

- Budgeting and fiscal management, including local government budgeting, performancebased budgeting, capital budgeting, multi-year budgeting

- Economic analysis and revenue forecasting, including micro-simulation, time series forecasting,

For more information about our technical assistance activities and training programs, please visit our website at http://aysps.gsu.edu/isp/index.html or contact us by email at hseraphin@gsu.edu. 


\title{
The Impact of Tax and Expenditure Policies on Income Distribution: Evidence from a Large Panel of Countries
}

\author{
Jorge Martinez-Vazquez*, Blanca Moreno-Dodson ${ }^{* *}$ and Violeta Vulovic* \\ * International Center for Public Policy, Andrew Young School of Policy Studies, Georgia State University. \\ ** The World Bank.
}

\begin{abstract}
The main focus of this paper is on the potential role that taxation and public expenditure policies play in general in affecting income distribution. We find that progressive personal income taxes and corporate income taxes reduce income inequality. The effect of corporate income taxes seems to be eroded away in open or globalized economies. We also generally find that general consumption taxes, excise taxes and customs duties have a negative impact on income distribution. On the expenditure side, we find that higher shares of GDP on social welfare, education, health and housing public expenditures have a positive impact on income distribution.
\end{abstract}

Keywords: Tax Policy, Public Expenditures, Income Distribution, Tax Progressivity JEL Classification: H23, H24, H51, H52, H53, H54

We are thankful to Krishanu Karmakar for research assistance. An earlier version of this paper was presented at the $4^{\text {th }}$ International Tax Dialogue Global Conference in New Delhi in December of 2011. 


\section{Introduction}

The last two decades have seen a general deterioration of income distribution in most countries around the world and even though the most recent data are not yet all available, all indications are that inequality has increased as a consequence of the 2008 world financial crisis and the following recession. ${ }^{2}$ And unlike earlier crises of a global scale, this most recent crisis may have a much more significant impact on the income distribution of OECD countries (Immervoll and Richardson, 2011). A variety of economic factors, such as increased globalization, corruption and other institutional failures, or demographic trends have been used to attempt to explain the forces driving larger inequalities in market incomes. The main focus of this paper is on the potential role that taxation and public expenditure policies play in general in affecting income distribution, positively or negatively, and to what extent changes in fiscal policies on the tax and expenditure sides of the budget around the world have contributed to slow down an ongoing deterioration of income distribution patterns- or alternatively, they have been conducive to such deterioration.

Over the last several decades there have been changes in the rates and structure of tax systems, as well as, important variation in the level and composition of public expenditures in both developed and developing countries. Our current knowledge of how taxes, transfers and public expenditure programs may affect income distribution has significantly improved on a country by country basis because of all the research effort that has been put in the tax and expenditure incidence literature. ${ }^{3}$ Much less research has been conducted on how changes in taxation and public spending trends have actually impacted income distribution trends, especially in developing countries. However, some evidence indicates that fiscal policies do affect income distribution trends. For example, Caminada and Goudwaard (2001) found that in the United Kingdom and the Netherlands, reductions in government spending in social programs making the welfare systems in those countries less generous have been accompanied by sharp increases in income inequality, although the causality has not been proven. Similar powerful effects have

\footnotetext{
${ }^{2}$ The evidence so far on the impact of the financial crisis on income distribution and the poor is reviewed in Cuesta and Martinez-Vazquez (2011).

${ }^{3}$ See Martinez-Vazquez (2008) and Cuesta and Martinez-Vazquez (2011) and the references there for reviews of these literatures.
} 
been attributed to fiscal policies in developing countries, such in the cases of Indonesia (Keuning and Thorbecke, 1989) or Latin America (Ocampo, 1998). On the other hand, some other authors have found a weak correlation between changes in government spending and income inequality (Schuknecht and Tanzi, 2005; Arjona, Ladaique and Pearson, 2001) or have claimed a general ineffectiveness of tax policy to affect income distribution (Harberger, 2006).

Clearly, there is at this point a need to better understand what role tax and spending policies have been playing vis-à-vis the changing trends in income distribution. Does the degree of effective tax progressivity play a role in improving income distribution? Does an increased share of revenues from VAT worsen income distribution? Are recent trends in expenditure policies offsetting or reinforcing the effects of changes in taxation on income distribution? These are some of the questions we analyze in depth in this paper using a large panel data set of developed and developing countries covering the period 1970-2006. The challenges we face are significant; not only it is difficult to come up with good measures of changes in income distribution comparable across countries but also it becomes quite difficult to identify and measure the most salient aspects of tax and expenditure policies as they are expected to impact income distribution.

Despite those difficulties, in our empirical analysis we find significant effects of both taxes and public spending on income distribution when they are considered jointly. These effects generally support the findings in individual country incidence analysis studies. Progressive income taxes, when considered separately, have a positive impact on income distribution, contributing to decreasing inequality, and this effect is more pronounced the higher the degree of progressivity and the higher the share of GDP that is collected with the individual income tax. Corporate income taxes also have a positive effect on income distribution but this effect seems to be eroded away in economies that are very opened or globalized, thus supporting Harberger's (1998) reinterpretation of the incidence of the corporate tax in open as opposed to closed economies. We also generally find, in accordance with individual country incidence analysis studies, that general consumption taxes, excise taxes and customs duties have a negative impact on income distribution. 
On the expenditure side, we find that higher shares of GDP on social welfare, education, health and housing public expenditures have a positive impact on income distribution, individually and collectively. In terms of the magnitude of the impact, the effects of taxes on income distribution changes tend to be of an equivalent scale to those for public expenditures. This is not necessarily consistent with the existing conventional wisdom of the higher ability of governments to pursue redistributional policies from the expenditure side of the budget as opposed to tax policy side. However, this is probably reflecting the fact that other public expenditures which are expected to affect positively income distribution are not included in the analysis mainly due to data limitation.

The rest of the paper is organized as follows. In section two we take a preliminary look at the data looking at the trends in income distribution, taxes and selected public expenditures for our sample of 150 countries for 1970 to 2006. In section three we review the literature putting especial focus on regression based studies of the impact of fiscal policies on income distribution. In section four we develop our empirical approach, with the different specification models and a discussion of the several econometric challenges we face. In section five we discuss the data. In section six we discuss our empirical findings. Section seven concludes.

\section{Trends on income distribution and tax and expenditure policies}

The last three and an half decades have seen considerable variation in the levels of income distribution inequality, as measured by the Gini coefficient. Figure 1 shows the evolution of the average Gini coefficient for our entire sample of countries, which is calculated in three different forms: unweighted, weighted by country GDP, and weighted by country population. ${ }^{4}$ Although the evolution of the three indexes varies somewhat, especially in the most recent years, two clear trends are apparent in worldwide income inequality. From the earlier 1970s to the middle of the 1980s income inequality decreased by all measures and at rapid pace. After stabilizing in the middle 1980s, inequality rose sharply especially in the early 1990s.

\footnotetext{
${ }^{4}$ There is no clear way to select the best representation of the trend but probably the population weighted index is the most attractive representation since inequality ultimately refers to people (Duncan and Sabirianova Peter, 2008).
} 
Both unweighted and weighted by GDP, Ginis showed declines in the early 2000s although the population weighted Gini continued to increase. We would expect all inequality measures to show increases after the world financial crisis of 2008 but those data are not yet available for a large number of countries.

Figure 1. Trends in Income Inequality as Measured by Gini Coefficients, 1970-2006

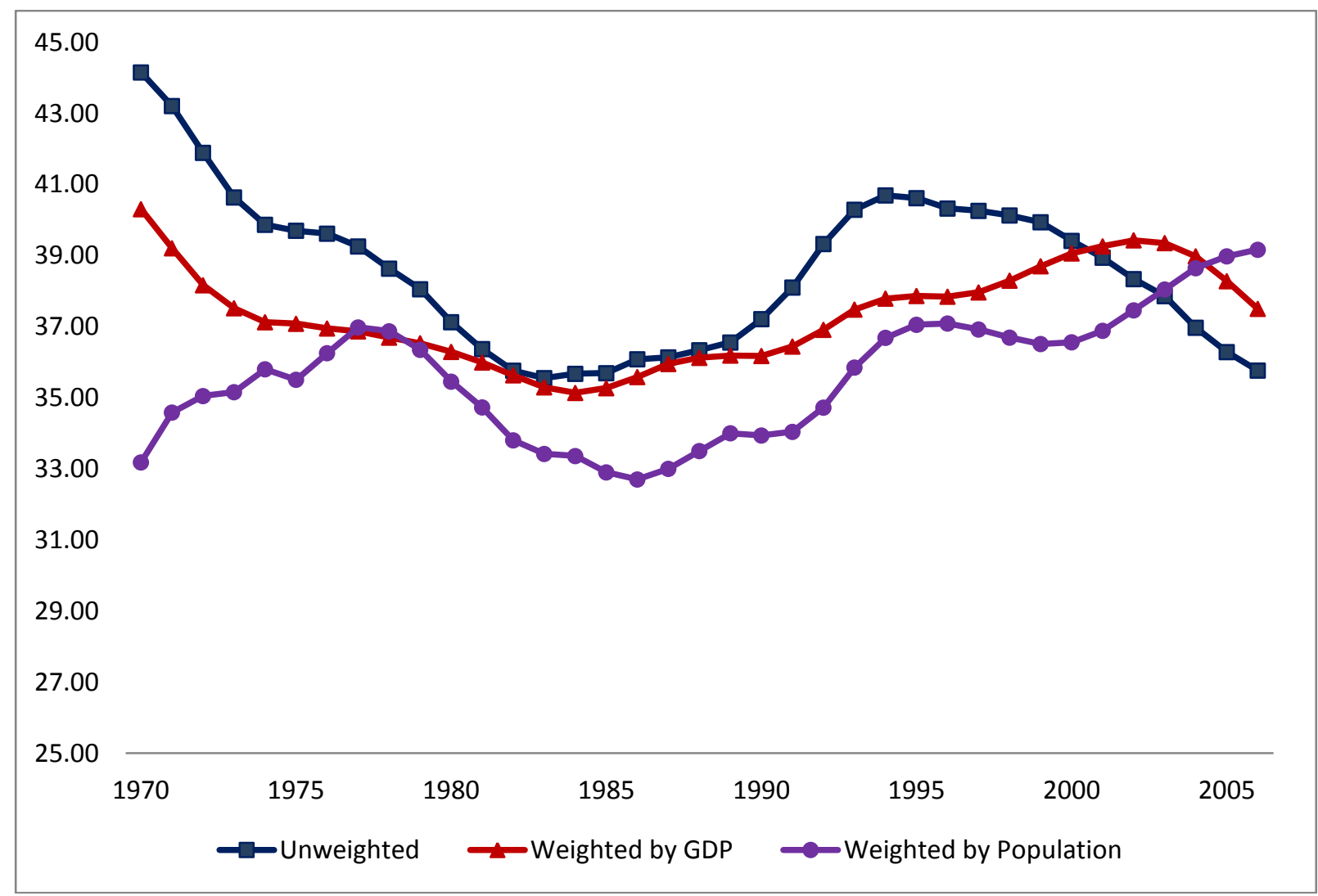

Source: Authors' calculations; World Income Inequality Database V2.0c May 2008

When looking at individual taxes, the overall personal income tax progressivity index ${ }^{5}$ has shown a pretty steady decreasing trend over the past 25 years (Figure 2).

\footnotetext{
${ }^{5}$ The personal income tax progressivity index is described further below in the data section.
} 
Figure 2. Trends in Personal Income Tax Progressivity (unweighted Gini) and Income Inequality, 1980-2005

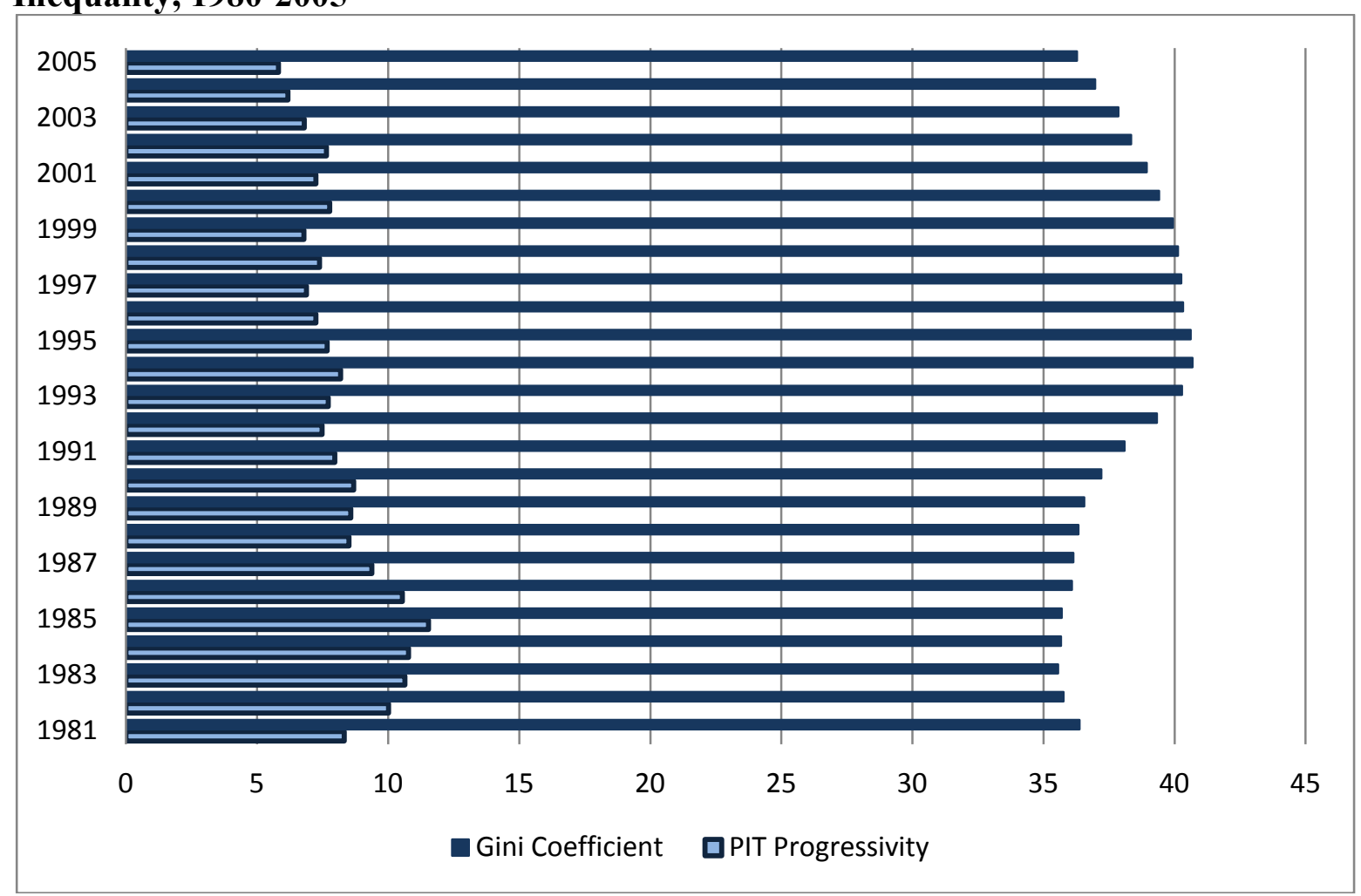

Source: Authors' calculations; Sabirianova Peter, Buttrick and Duncan, 2010; World Income Inequality Database V2.0c May 2008

Thus, from just a general look at the data, there does not appear to be a major correlation with inequality and personal income tax progressivity. However, the trends for the different taxes measured as "collections as \% of GDP" shown in Figure 3 indicate that is there is perhaps a closer general correlation between tax policy and the trend in income inequality. 
Figure 3. Trends in Taxation (as \% of GDP raised with each tax) 1972-2009

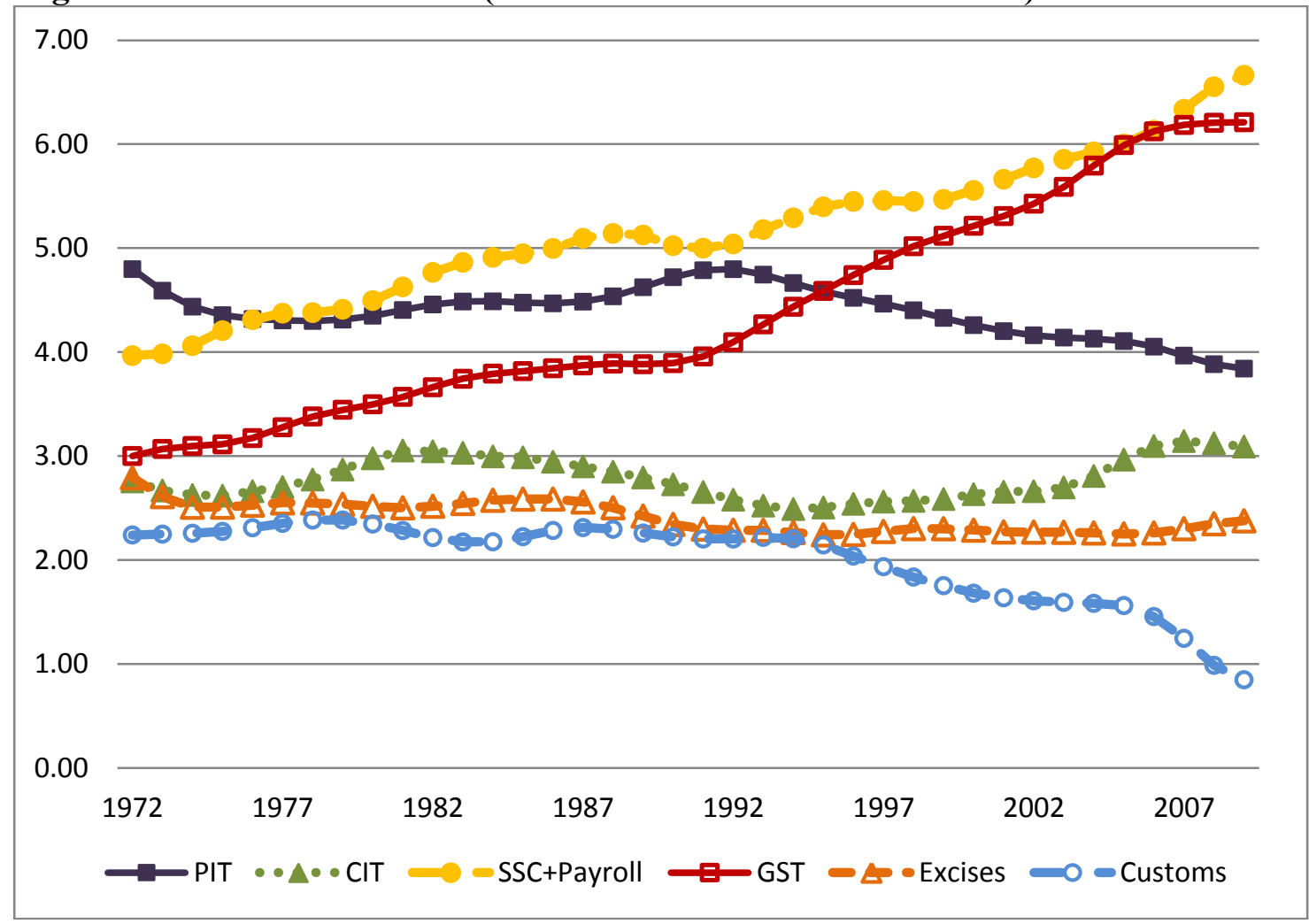

Source: Authors' calculations; IMF GFS Database; OECD Revenue Statistics, CEPAL

We can see there were significant increases in average tax collections worldwide in 'social security contributions" plus payroll taxes and general consumption taxes (VAT), two taxes that are generally thought to be regressive, for over the 25 year period. ${ }^{6}$ The increases are specially pronounced since the late 1980s. In addition, also from the late 1980s we can observe a significant decrease in the importance of personal income tax, the tax that is generally accepted has the largest potential to redistribute income. Any impact of the decline in personal income taxes should have come to reinforce the impact of the general decline in the progressivity index we saw in Figure 2; that is, not only did the personal income tax become less important in terms of collections but also it became less progressive. For other taxes, we can also see in Figure 3 a long declining trend over the entire period, but especially so since the early 1990s in customs duties. This tax is generally thought as having a regressive incidence, so the smaller collections in customs duties should have helped reduce income inequality; but, we also must note that this tax is much smaller in terms of GDP than for example social security contributions or general

\footnotetext{
${ }^{6}$ The general incidence of taxes is described in the review of the literature below.
} 
consumption taxes. In the case of the corporate income tax, collections as a share of GDP have experienced a rollercoaster ride for the last 25 year, with an increasing swing since the early 1990. This is a tax that is generally thought to be progressive, although less so, and can be even regressive the higher the degree of openness of the economy; also, this tax is of relative less importance in terms of collections. Last, excise taxes have also been on a bit of a rollercoaster and in the upswing since the early 1990s. Like in the case of general consumption taxes, excises are generally thought to have a regressive incidence. However, their effect varies per country depending on whether or not they are applied to luxury or basic items for the population, and on the consumption preferences of citizens.

As we discuss immediately below in the review of the literature, while taxes are generally thought to have a limited amount of power to impact income distribution, public expenditures are generally thought to have larger potential to affect it. In this paper, we particularly focus on four categories of public expenditures that have a priori significant potential on reducing inequality in the distribution of income: public expenditures on social protection, education, health, and housing, all expressed as "\% of GDP." The worldwide trends in these expenditure categories are shown in Figure 4.

Figure 4. Trends in Public Spending (as \% of GDP spent for each category), 1972-2009

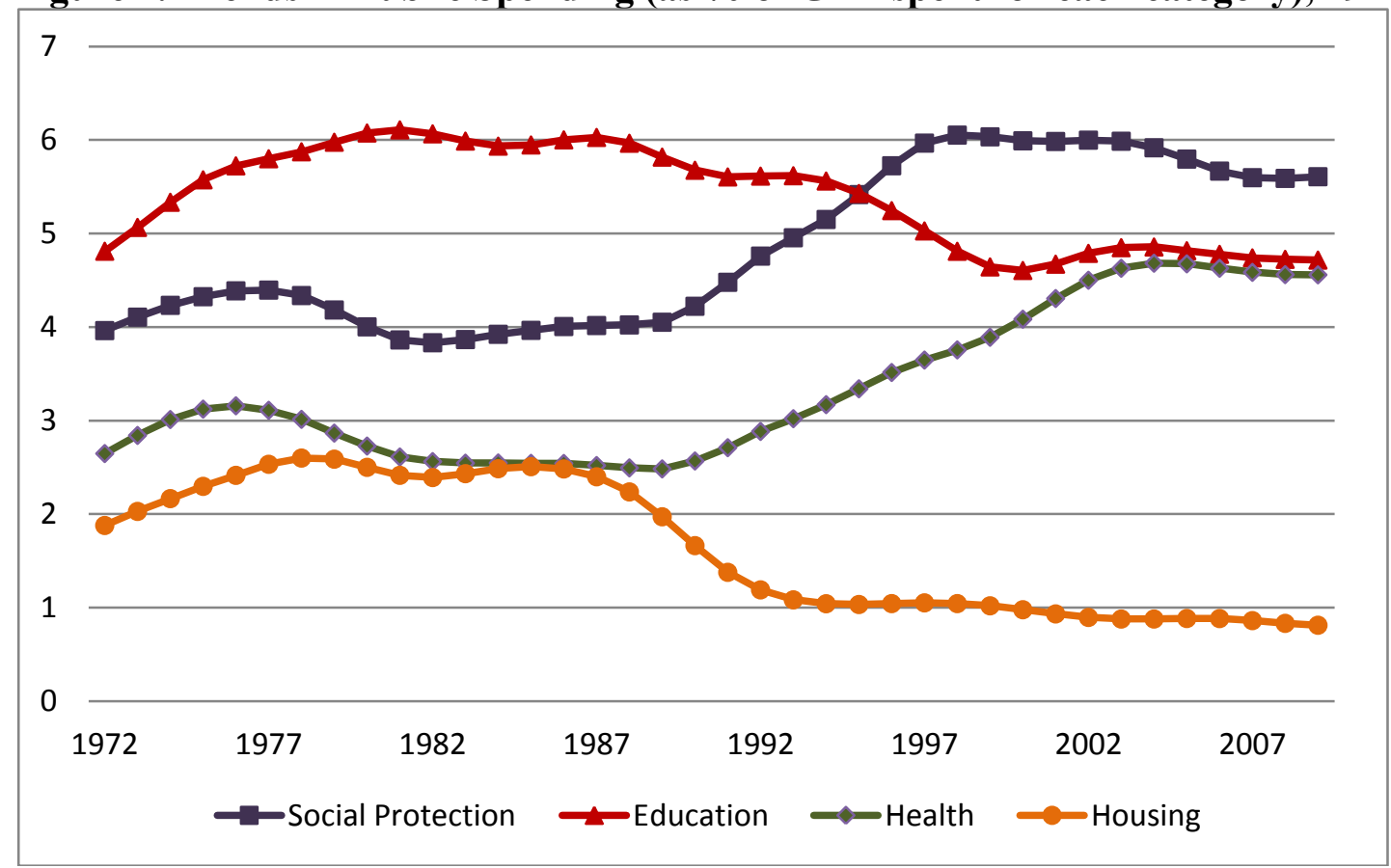

Source: Authors' calculations; IMF GFS Database, OECD Social Expenditure Database; International Food Policy Research Institute (IFPRI) 
The potentially redistributive expenditures on "social protection" have increased steadily since the early 1980s reaching a peak in the early 2000s and then declining slightly in the most recent years. Public expenditures on health also have steadily increased since the 1980s reaching a plateau and then declining slightly in more recent years. On the other hand, public expenditures on education have decreased significantly since the end of the 1980s. Depending on the composition and access of lower income groups to education and health services (for example, primary health which tends to be progressive especially when there is access in poor rural areas versus tertiary hospital services which tends to be regressive) they can also significantly affect inequality in the distribution of income. Since expenditures on public health increased during the period, this should have contributed to decreasing inequality. And because public education expenditures decreased, this should have contributed to increasing income inequality. However, the effect of both health and education expenditures on income distribution depend intrinsically on the intra-sectoral composition of spending in both sectors and the degree of access of the poorest segments of the population to the public services provided. For example, it is expected that primary education benefits the poor provided they can access it and its quality is good, while tertiary education may benefit more the richer segments of society. Similarly accessible primary medical care is expected to benefit the poor relatively more while advance medical care may often be affordable only to richer groups. The fourth category of public expenditures on housing has steadily declined since the mid-1980s with potentially negative effect on income distribution.

Clearly, the discussion above can only be taken as indicative and suggestive of the directions in which tax and public expenditure policies may be correlated with the trends on income inequality. The overall picture would seem to be that the worldwide trends in tax policy have not been conducive to reducing income inequality but, if anything, to increase it. Higher overall reliance on regressive indirect and payroll taxes and a reduced importance and degree of progressivity of personal income taxes tells the story. On the expenditure side, the decline in public housing expenditures but more importantly in education expenditures points toward a negative impact increasing income inequality, while the increased expenditures on social protection services and public health could have had offsetting effects, contributing to reducing inequality. Only careful econometric analysis can help us establish to what extent the increases in public expenditures on health and social protection may have offset those trends and overall 
helped improve equality in the distribution of income. The econometric analysis is presented in section 4 .

\section{Review of the literature}

\section{Taxes and income distribution}

The interest in the impact of tax structure on income distribution dates back to Meltzer and Richard's (1981) hypothesis that when mean income rises relative to the median income in the income distribution, a majority coalition of those with lower income will tend to support higher taxes, presumably more in the form of direct, and progressive, taxes as opposed to indirect taxes. ${ }^{7}$ There is a fairly large applied literature on tax incidence, allocating tax burdens among different income groups according to a conventional set of assumptions about tax shifting. These assumptions in the conventional tax incidence literature include the following: (i) the individual income tax is typically assumed to be progressive; (ii) payroll and social security taxes are typically assumed to be fully shifted to workers and regressive due to the cap on income to structure contributions; (iii) the corporate income tax is typically assumed to be paid by capital owners and therefore progressive, but less so in open economies where the tax gets shifted to immobile factors, mainly labor; (iv) taxes on goods and services, including several forms of sales taxes, value-added taxes, excises taxes, and also customs duties are practically all the time assumed to be shifted forward to consumers, i.e. they are assumed to be regressive, although the exemption and lower rates for basic commodities can reduce the regressivity of value added taxes and excise taxes on luxury items can be highly progressive.

In his seminal paper on incidence of corporate income tax, Harberger (1962) shows that in a closed-economy with two perfectly competitive sectors and fully mobile factors of production, imposing a tax on capital in one sector would cause capital to move from the taxed to the untaxed sector, further causing reallocation of labor among two sectors and changes in factor and output prices. Using elasticities typical for the U.S. economy, Harberger finds that, in these circumstances, capital bears approximately the full burden of the corporate income tax. In his

\footnotetext{
7 Borge and Rattso's (2004) work for Norwegian local governments in 1996 supports the Meltzer-Richard hypothesis.
} 
two more recent papers, Harberger $(1995,2006)$ revisits the incidence of CIT in an open economy where capital can flow freely across the international borders and finds that, in this case, the burden of a corporate tax is more than fully shifted to labor. To account for this dimension of CIT, we interact CIT variable with globalization index. Our results provide support for Harberger's $(1995,2006)$ findings. In a closed economy, one percentage point increase in share of CIT to GDP reduces income inequality by 0.7 percentage points. However, the more open an economy is, the lower is this negative effect on income inequality - 10 points increase in the globalization index reduces negative effect of CIT on income inequality by 0.1 percentage points.

Most of the empirical studies on tax incidence are country-specific studies relying on microsimulation models and computable general equilibrium models. The general conclusion reached in this literature is that the redistributive effects of taxes are weak, especially so for developing countries (Bird and Zolt, 2005; Harberger, 2006; and Martinez-Vazquez, 2008). However, some of these papers have found significant effects for large changes in tax structure. For example, for the United States, Li and Sarte (2004) find that the progressivity change associated with the Tax Reform Act (TRA) of 1986 had a significant effect on income inequality decreasing the Gini coefficient in four percentage points. See also Gravelle (1992).

There has been less empirical work on the impact of the tax structure on the distribution of income across countries. Weller (2007) uses cross-country data from 1981 to 2002 and finds positive effects of progressive taxation on income distribution. More recently, Duncan and Sabirianova Peter (2008) use a sophisticated measure of progressivity ${ }^{8}$ to examine whether inequality in the distribution of income is affected by their measure of structural progressivity of national income tax systems. Their main finding is that while progressivity reduces observed inequality in reported gross and net income, as measured by the Gini coefficients based on those data, it has a significantly smaller impact on "true inequality", which they argue is approximated

\footnotetext{
${ }^{8}$ Their measure of progressivity for the individual income tax, which is also used in this paper, is fully developed in Sabirianova Peter et al. (2010).
} 
by consumption-based measures of the Gini coefficient. ${ }^{9}$ However, Duncan and Peter (2008) do not take into account the fact that the impact of progressivity on income distribution also depends on the relative importance in GDP of income tax revenues; highly progressive income taxes but with relatively small collections is likely to have less of an impact on income distribution.

\section{Public spending and income distribution}

The oldest literature that ties public spending, growth and income distribution is on the Kuznet's (1955) hypothesis on the existence of an inverted U-curve relationship between economic growth and the distribution of income, mainly stating that growth of national income is initially accompanied by increased inequality before the fruits of growth gets more equitably divided in society. However, the hypothesis is vague with respect to the duration of the period during which income distribution should become more skewed nor is explicit about any role that public spending may play in this process. The Kuznet's hypothesis has been tested and researched for a good number of decades with, at best, mixed results. ${ }^{10}$

More recent research on public expenditure and income distribution has been concerned with the effectiveness of government policy in improving or at least mitigating the worsening of income distribution. Independently of whether Kuznet's hypothesis holds in its entirety or not, there has been an increasing consensus that economic growth per se may not be sufficient to reduce inequalities already present in the income distribution. As Tanzi and Chu (1992) have argued, without any redistributive government policy, even very large growth rates can fail to achieve any significant reduction in poverty rates and income inequality.

Government policies, specifically expenditure policies, can bear heavily upon the qualitative results of economic growth. It has been also increasingly acknowledged that the nature of

\footnotetext{
${ }^{9}$ Due to the presence of tax evasion, Duncan and Peter (2008) argue that under some conditions tax progressivity may induce increased inequality in the distribution of actual income (as measured by consumption) as opposed to observed income.

${ }^{10}$ Even though a good number of researchers have found that they cannot reject this hypothesis using cross-section data, others, starting with Clarke (1992) have argued that this hypothesis is basically of time-series nature and hence should not be tested with cross section data. In addition, some other authors, such as Bruno, Ravallion, and Squire (1998) and Anand and Kanbur (1993) have argued that with cross section data a careful monitoring of the measures of inequality across countries leads to the rejection of the Kuznet's hypothesis.
} 
economic growth can have discernible impacts in the distribution of income. In particular, contrary to the traditional economic argument that explicit redistributive policies can hamper economic efficiency and growth, ${ }^{11}$ it is now widely recognized that redistribution policies, such as in the form of human capital development amongst the poor, actually fosters growth. ${ }^{12}$

However, there has been also wide acknowledgement, going as far as Tanzi (1974), that what in many instances would seemingly be perceived as redistributive government spending may do nothing to improve income inequality and may actually worsen it. This is due to the issue of the difficulty of targeting of distributional expenditure policies which has been discussed buy a number of authors (Aspe and Sigmund, 1984; Aspe, 1993; Birdsall and James, 1993; Gonzalez, 1995; Harberger, 1998; Schwartz and Ter-Minassian, 2000). It is quite difficult to target the poor with regular education and health spending because, among other reasons, these programs are in many countries located in urban areas thus not directly benefiting the rural poor or even those in the informal settlements in urban areas. Beyond the inherent problems of designing effective redistributive public expenditure programs, other authors have emphasized the role of political economy, and in particular the political clout of certain groups, in effectively controlling the amount of redistribution that actually takes place in any country (Hausmann and Rigobon, 1993; Alesina, 1998).

Of course, it is to be expected that the quality of targeting makes a big difference in the final outcome. In spite of the caveats above, many education and health spending programs have been found to be equalizing and 'poverty reducing' (Paternostro et al., 2007). Others have found that infrastructure spending in some developing countries has resulted in large poverty reduction (for

\footnotetext{
${ }^{11}$ The previous 'traditional' wisdom draws heavily from the Keynesian hypothesis about differences in the propensity to save, thus that higher income to the affluent implies higher savings and investment which leads to increases in economic growth; hence, the tradeoff between redistribution and the size of the pie in the macro sense. For example, most recently, Alfranca and Galindo (2003) found for 19 OECD countries that public expenditure positively affects growth and in addition that increased inequality in income distribution also has a positive impact on growth.

${ }^{12}$ But it is also widely acknowledged that that there are instances of seemingly redistributive government spending which do nothing to improve income inequality, and may actually worsen it. For example, Gonzalez (1995) found in the cases of public education expenditures in Peru, such public 'merit' good spending was actually benefitting the non-poor and hence exacerbating the extant skewed distribution of income. The poor targeting of distributional expenditure policies is discussed by Harberger (1998).
} 
example, Klump and Bonschab, 2004 in the case of Vietnam) but their effects on inequality are unknown. ${ }^{13}$

In the recent literature much more emphasis has been placed on the relationships between growth and income distribution (Dollar and Kraay, 2000), and public spending and growth (Afonso, 2005; Herrera, 2007; Moreno-Dodson, 2008; Bayraktar and Moreno-Dodson, 2010; Day, 2011). It is now quite clear that the quantity and quality of growth is affected by public expenditure, and growth in turn affects the distribution of income. Not only that, the nature of growth resulting from the public efforts is also affected by the existing income distribution (Alfranca and Galindo, 2003).

The actual research in to the direct relationship between public spending and income distribution continues to be much more concentrated on the impact or benefit analysis of particular types of government expenditure on particular income groups (like the poor) instead of the income distribution in general (Martinez-Vazquez, 2008). Nevertheless, there are a few studies that have focused on the wide impact on income distribution, either for a particular country or in cross country analyses. For example, de Mello and Tiongson (2006) in a cross-country analysis (the sample running from 27 to 56 countries depending on availability of data) of the impact of government spending on income distribution find the overall effects to be un-equalizing. In fact, those countries where redistribution is most needed due to high inequality, they are also less likely to have effective redistributive policies in place. In the case of country studies, for Brazil Clements (1997) similarly finds that government social expenditures have contributed to exacerbate income inequalities. On the contrary, Jao (2000) finds that in the case of Taiwan public expenditures on social assistance and social insurance contributed positively in reducing income inequality. However, a number of developing countries worldwide have implemented conditional cash transfers systems that link spending to actual use of the public service being provided, leading to better impact of government social spending on the poor ${ }^{14}$.

\footnotetext{
${ }^{13}$ But here again the rent seeking behavior of the elite can change the outcomes, as identified by Araujo (2008) for Ecuador and Khemani (2010 for India.

${ }^{14}$ See for example Bolsa Familia in Brazil and Progresa in Mexico.
} 
In a recent paper, Boustan et al. (2010) looked at the relationship between government spending and income inequality from exactly the opposite angle. For counties and municipalities in the United States (for 1970-2000) they analyzed the effect of inequality on public spending. They find that as inequality rises (across time and across regions) public spending rises as well. ${ }^{15}$ However, those increased expenditures are mainly over police, fire protection, road maintenance, but also schools, while financing has continued to shift from property taxes to other sales and other more regressive taxes. Thus Boustan et al., (2010) conclude that although inequality results in higher spending, tax financing and spending programs as a whole do not contribute to improving income distribution, which fits well into the evidence of a widening income gap in the USA (Smeeding, 2004; Caminada and Goudswaard, 2001). ${ }^{16}$

In summary, the literature has focused on the relationships between growth and income distribution, and between public spending and growth. On the relationship between public spending and income distribution, considerable research efforts have mainly concentrated on the impact of particular types of spending on different income classes. Much less research effort has gone into analyzing the effect of the variability of public spending composition on the distribution of income as a whole. No doubt this latter type of research has been hampered by the unavailability of uniform data across countries not only for income distribution itself but also for public spending. Overall, it would seem fair to conclude that the evidence so far suggests that properly targeted public expenditure in social welfare and in human capital formation, such as health and education, has the potential to affect income distribution positively especially when effectively targeted, which unfortunately is proving hard to design and implement.

\footnotetext{
${ }^{15}$ According to their estimates, "average increase in the city-level Gini Coefficient over this period (5 points) leads to a $\$ 63$ increase in expenditures per resident".

${ }^{16}$ For individual country studies on the impact of taxes and transfers on income distribution recent papers include Riihelä et al. (2008) for Finland and Glennerster (2006) and Adam and Browne (2010) for the United Kingdom. In terms of cross-country studies, there are a number of papers that have investigated specific government policies, such as the impact of social transfers in the EU by Heady et al. (2001). Other studies have focused on the progressivity of the personal income tax (Peter et al., 2009; Wagstaff and van Doorslaer, 2001, Wagstaff et al., 1999). For previous multi-country comparative study see also Immervoll et al. (2006).
} 


\section{The interaction of taxes and public spending and income distribution}

There has been less research looking at the combined effects of taxes and public expenditures on income distribution. In a recent study for Brazil, Baer and Galvao (2008) found that when the tax and expenditure system are considered together, the system tends to favor the higher income classes. Also, Immervoll and Richardson (2011) recently studied the impact of tax-benefit systems in OECD countries over the last two decades. They focus on inequality trends among "non-elderly" households and on the role played by the personal income tax and social security taxes paid by employees on the one hand, and cash transfers received, such as unemployment benefits etc, on the other hand. They conclude that even though tax-benefit systems have become more redistributive since the 1980s, that trend has not been large enough to offset the increasing trend in market- income inequality which grew by twice as much as redistribution. In addition, the redistributive strenght of tax-benefit systesm weakned in many OECD countries beween the mid 199os and the mid 2000s. They also conclude that in terms of redistribution strength, direct "benefits" had a much stronger impact on redistribution than personal income taxes and social security contributions, despite the much larger relative size of these taxes in GDP vis-à-vis direct benefits paid. Because of this composition of redistributive tools, redistributive policies in OECD countries have been more effective in closing income gaps at the botom of the income distribution than at the top. In restoring incomes at the bottom of income distribution the most effective policy is to encourage employemnt and earnings growth amongs these groups.

\section{Empirical Estimation Approach}

This section discusses the methodology we apply to test the relationship between tax system and expenditure structure, and income inequality. We use a multivariate regression framework to analyze the impact of personal income tax, other taxes, and public expenditures on income distribution. This is a departure from most previous studies, that as we saw in the review of the literature above, use microsimulation techniques to estimate that impact in a country specific context. From the outset we need to be aware that this approach also has limitations. For one, we are limited in the full recognition of within country heterogeneity regarding policy instruments in the tax and expenditure sides, behavioral responses by households and so on. However we are 
able to account for the impact of most taxes and spending patterns on a large international scale with cross-country comparisons and the evolution overtime of within-country variations in policies and changes in income distribution.

Income inequality is measured here by the Gini coefficient, although of course inequality has many other dimensions. ${ }^{17}$ The term "redistribution" is used to mean a reduction in income inequality as measured by the Gini coefficients as the result of government policies controlling for other factors that typically have been identified in the past literature as significant determinants of income distribution. On the side of government policies we consider all direct and indirect taxes, ${ }^{18}$ as well as a variety of government expenditures beyond social welfare expenditures. ${ }^{19}$ We take a long run view of how tax and expenditure policies may have affected income distribution over a continuum of $30+$ years. . Using a multi-country study can be criticized because even though income distribution is affected by a set of common factors across countries, there are many institutions and processes that are particular to each country that cannot be reflected in the variables used in the regression. However, this issue is minimized because in our estimation technique we control for those fixed country effects.

We consider first the tax side alone; the expenditure side alone, and both sides tax and expenditure, and compare how this affects the estimated coefficients. The impact of changes in taxes on income distribution is captured using ratios to GDP. The larger the share of any particular taxes on GDP, the larger the potential impact (positive or negative) on income distribution.

\footnotetext{
${ }^{17}$ We do not take into account other dimensions of inequality broadly defined which are not measured by income.

${ }^{18}$ Most studies in contrast have focused on the impact of individual income and social security taxes paid by employees. The rationale to control for the impact of other taxes is that each of them has a different final economic incidence which is expected to affect the final distribution of income. Thus for example, the burden of portion of social security taxes formally paid by employers is widely accepted falls on employees. Sometimes it is argued that consumption taxes are excluded from the analysis because they do not have a direct impact of income. However they do have a direct impact on the level of consumption and our measures of Gini also include Gini measured based on consumption. The inclusion of corporate income taxes is also justified because the final incidence of corporate income tax may be in lowered wages and labor income depending on the final economic incidence of the CIT.

${ }^{19}$ For example, public expenditures on health and education have the potential of increasing human capital of lower income groups and therefore reduce income inequality.
} 


\section{The model}

In investigating the impact of tax and expenditure policies on income inequality, we focus on the evolution of the Gini coefficient, which is computed on the basis of income distributions using different concepts of income, including gross income, net income and consumption. This presents some measurement and comparability issues that we can only partially address below. We are interested in finding out how the tax structure and its progressivity, as well as public spending and a set of other control explanatory variables, have affected the Gini coefficient over time in our sample of countries.

It is almost certain that income inequality in a current year depends on its level(s) in previous year(s) and a set of variables that is commonly used in the literature to explain income inequality (see Milanovic, 2006; De Gregorio and Lee, 2002; Gupta, Davoodi, \& Alonso-Terme, 2002). Starting from this assumption, we test the overall hypothesis that both tax and expenditure structures are important determinants of income inequality. Therefore, the model to be estimated has the following form:

$$
\operatorname{gini}_{i t}=\alpha \operatorname{gini}_{i t-1}+\gamma F_{i t}+\beta X_{i t}+v_{i}+\varepsilon_{i t}, \quad i=1, \ldots, n ; t=1, \ldots, T
$$

In equation(1), gini $i_{i t}$ represents the gini coefficient in country $i$ in year $t, i=1, \ldots n, t=1, \ldots T$, while gini $_{i t-1}$ represents its value in year $t-1$. Next, $F_{i t}$ stands for a vector of fiscal variables representing tax instruments and public expenditures in country $i$ in year $t$. The variables representing tax instruments are personal income tax (PIT), corporate income tax (CIT), social security contributions (SSC) and payroll taxes, general sales tax (GST), excises, and customs duties. On the expenditure side we focus on four types of public expenditures that we can anticipate can have significant differential impacts on income distribution; namely, expenditures for social protection, for education, for health, and for housing. The vector $X_{i t}$ represents the set of control variables that have been consistently found to play a significant role in explaining income inequality in the previous literature. These include population growth, age dependency, the level of globalization, GDP per capita growth, unemployment, the extent of corruption, education level, and the size of government. Finally, in the error term, $v_{i}$ stands for unobserved 
country fixed effects. Further discussion of all the variables of interest and control variables is provided below in this section.

We need to address several econometric problems that may arise in the estimation of equation (1). First, the variables representing tax instruments and public expenditures in $F_{i t}$ are likely to be endogenous, due to reverse causality- from income inequality to chosen fiscal policy instruments and vice versa. In particular, countries with higher income inequality may choose to rely relatively more on direct taxation and/or public expenditures, and vice versa. As a result, these regressors may be correlated with the error term. This reverse causality between inequality and progressive measures largely based on the median voter model goes back to Meltzer and Richard (1981) and it has been further developed by Persson and Tabellini (1999) and others. It is hypothesized that as income distribution becomes more unequal and skewed, lowering the ratio of median to mean income, a majority of voters in a coalition with the median voter is more likely to vote for higher taxes and greater levels of redistribution. Besides this argument for potential reverse causality, endogeneity may also arise due to omitted variables and measurement error. $^{20}$

Time-invariant unobserved country fixed effects may be correlated with the explanatory variables. The fixed effects are contained in the error term $u_{i t}$ in equation (1), which consists of the unobserved country-specific effects, $v_{i}$, and the observation-specific errors, $\varepsilon_{i t}, u_{i t}=v_{i}+$ $\varepsilon_{i t}$.

Third, the presence of the lagged dependent variable gini $i_{i t-1}$ is likely to give rise to autocorrelation. Finally, the panel dataset has a relatively short time dimension $(\mathrm{T}=30)$ and relatively larger country dimension $(\mathrm{N}=150)$. This causes a potential problem because when the time period is short, the correlation of the lagged dependent variable with the error term, and hence the dynamic panel bias, may be significant. In this case, applying a straightforward fixed effects estimator would not be appropriate (Roodman, 2006).

\footnotetext{
${ }^{20}$ If the time invariant country characteristics are correlated with the error term, these omitted variables can create an endogeneity bias. The measurement error bias is due to the fact that the progressivity index is after all itself an estimated parameter with large or smaller standard errors. See Duncan and Sabirianova Peter (2008).
} 
To address the endogeneity problem, one would usually choose an instrumental variables approach. However, finding good instruments for all observed types of taxation and public expenditures is a significant challenge. For example Duncan and Sabirianova Peter (2008) address the endogeneity of their progressivity measure by using an instrumental variable corresponding to the progressivity measures from neighboring countries weighted by distance and population. ${ }^{21}$ Using OLS is likely to yield biased and inconsistent estimated coefficients given the presence of heterogeneity among countries. However, using a fixed effects estimation to account for that heterogeneity is questionable given the small variation in the Gini coefficients (the dependent variable) for a significant part of the sample. To address the second, third and fourth potential problems, we use the GMM estimator (Arellano and Bond, 1991), which was first proposed by (Holtz-Eakin, Newey, and Rosen, 1988). The difference GMM estimator uses first differences to transform equation (1) into

$$
\Delta \operatorname{gini}_{i t}=\alpha \Delta \operatorname{ginig}_{i t-1}+\gamma \Delta F_{i t}+\beta \Delta X_{i t}+\Delta \mathrm{v}_{i}+\Delta \varepsilon_{i t}
$$

Because fixed country-specific effects do not vary over time, they disappear by this transformation, solving problem (2). That is,

$$
\Delta u_{i t}=\Delta \mathrm{v}_{i}+\Delta \varepsilon_{i t}
$$

or

$$
\begin{aligned}
& u_{i t}-u_{i t-1}=v_{i}-v_{i}+\varepsilon_{i t}-\varepsilon_{i t-1} \\
& u_{i t}-u_{i t-1}=\varepsilon_{i t}-\varepsilon_{i t-1}
\end{aligned}
$$

The autocorrelation problem is addressed by "instrumenting" the first-differenced lagged dependent variable with its past levels. Also note that the Arellano - Bond estimator is designed for small-T large-N panels. In large-T panels, a shock to the country-specific fixed effect, which appears in the error term, declines with time. Similarly, the correlation of the lagged dependent variable with the error term is insignificant (Roodman, 2006). On the other hand, if $\mathrm{N}$ is small,

\footnotetext{
${ }^{21}$ The basic assumption is that tax progressivity in a country does not have an independent effect on the distribution of income in the neighboring countries, so the instrumental variable is expected to be uncorrelated with the error term in the regression explaining inequality in the original country.
} 
the cluster-robust standard errors and the Arellano-Bond autocorrelation test may be unreliable. In these cases, using the Arellano - Bond estimator would not be necessary.

\section{Variables and data}

This study uses an unbalanced panel data on 150 developed, developing and transition countries, between 1970 and 2009. The dependent variable, income inequality, is measured by the Gini coefficient. Given low data coverage for Gini coefficients and also, the more surprising, scarcity of data on tax collections and especially public expenditures, the actual number of observations used in each regression is often significantly reduced.

\section{Measuring income inequality}

The consumption based Gini coefficients have the advantage that they can be interpreted as being a better approximation of permanent income (Duncan and Sabirianova Peter, 2008). Beyond the limitation of measuring inequality in the distribution of income with the Gini coefficient, we also need to acknowledge that in the presence of considerable tax evasion due to informality and unreported income, the changes in observed income are not be necessary the same as those in true income (a point developed also in Duncan and Sabirianova Peter, 2008).

From the theory and practice of tax incidence we anticipate that progressive personal income taxes should contribute to a more equal distribution of income the more so the larger the PIT revenue collections are as a share of GDP and the higher the progressivity of the PIT. In particular, progressivity is measured as average rate progression up to an income level equivalent to $\mathrm{y}$ (where $y$ is a country's per capita GDP), which is a measure of PIT progressivity developed by Peter, Buttrick, and Duncan (2010). On their formal structure, personal income taxes over the past three decades have experienced a reduction in the number of tax rate brackets, maximum statutory rates and also complexity. These trends are highlighted by the large number of countries that have adopted flat rate PITs, especially in Eastern Europe and the Former Soviet Union countries. 


\section{Measuring income tax progressivity}

Here we will use the measure of progressivity developed by Sabirianova Peter et al. (2010). As these authors point out, progressivity has been measured in the literature by either identifying the top statutory rate in the personal income tax schedule which has obvious limitations given the complexity of most personal income taxes, or in the form of an effective inequality-based index which requires before and after taxation measures of income distribution, or structural progressivity measures which capture changes in in average and marginal rates along the income distribution which do not require information on after-tax outcomes in income distribution (Musgrave and Thin, 1948). This latter is the approach followed by Sabirianova Peter et al. (2010). They produce a single, comprehensive measure of PIT progressivity by first deriving average and marginal tax rates along the income distribution (using the country's GDP per capita and its multiples as a comparable income base) and then applying the tax schedule and structure information (standard deductions, personal allowances, tax credits, and so on) to arrive at the taxes due and the marginal and average effective tax rates.

\section{Variables of Interest: Taxes and Public Expenditures}

As this study investigates the effect of government tax and expenditure policy on income inequality, our variables of interest are individual tax instruments and certain types of public expenditures. We discuss first the separate tax instruments. Here, our ex ante expectations of the impact of each tax on income inequality is based on what is generally accepted in the tax incidence literature (Martinez_-Vazquez, 2008).

Personal income taxes generally are assumed to be progressive, contributing to lower income inequality. However, not all personal income taxes are created equal in terms of their structure and resulting overall level of progressivity, thus to identify the impact of the PIT on income inequality it becomes very important to observe its level of progressivity. For that reason, we interact the personal income tax variable with a personal income tax progressivity measure derived by Peter, Buttrick and Duncan (2010).

In the case of corporate income taxes, the conventional wisdom on its incidence is much more controversial. To the extent that the tax falls on capital income recipients, the CIT is a 
progressive tax. However, with high capital mobility and globalization, a higher share of its tax burden will tend to fall on internationally less mobile factors of production, namely labor. To allow for this difference in final incidence, the CIT variable is interacted with an index of globalization for each country, which is discussed further below. The more open the economy the higher share of the CIT that would fall on labor income making this tax less progressive.

While PIT can be progressive, social security contributions and payroll taxes can be regressive, i.e. representing a larger part of pretax income for low income workers. Social security contributions and payroll taxes are commonly shared between employees and employers. However, it is commonly accepted in tax incidence theory that employers tend to almost entirely shift the burden to employees in form of lower wages. And unlike the case of the PIT and CIT, social security contributions and payroll taxes are generally thought as not being progressive and possibly regressive because in most cases contributions are capped with income, so the overall burden or average rate tends to decreases with income.

As indirect taxes are ultimately paid by consumers, and lower income groups spend a higher share of their incomes, relatively higher reliance on general sales taxes, excises and/or customs duties is generally expected to result in higher real income inequality. However, the most important of indirect tax sources, the general consumption tax or value-added tax (VAT) can be designed with some features (exemption of basic commodities, lower rates, and so on) that can significantly mitigate the regressivity of this tax. To allow for differences on the impact of the VAT and other indirect taxes on inequality we introduce each of these taxes separately in the regressions. We must note also that among excise taxes, there are some that can be highly regressive (e.g., a tax on kerosene fuel, used mostly by poor households in developing countries) or quite progressive (e.g., surtaxes on some luxury items mostly consumed by high income households). Unfortunately the data we have does not allow us to differentiate among the different excises.

On the public expenditure side, we focus on four important types of public expenditures (by functional classification) which can be expected to have a significant impact on reducing inequality; namely, social protection, education, health, and housing expenditure. As in case of 
taxes, expenditures are too expressed as a percentage of GDP. These four types of expenditure have functions that target households and individuals in order to improve their welfare. The logic is that the higher the ratio of GDP that is dedicated to these different types of expenditures, the more likely income distribution will improve. This will be so in terms of market income (gross and net) for higher expenditures on human capital creation services such as health and education and on social welfare expenditures having to do with income protection and maintenance programs. In the case of other public expenditures, such as housing, they may also have a positive impact on equality, especially when this is measured in terms of the distribution of consumption.

It is very likely that within each of these aggregate categories of spending, incidence of subcategories would vary, so it would be ideal to observe more disaggregated categories of public spending. Ideally, the data should identify under social protection those programs that have the highest impact on inequality, such as cash transfers programs to the unemployed or elderly as well as income tax credits or transfers to low income households. Unfortunately, at this point data with such level of disaggregation does not exist at the international level. Similarly, it would be very desirable to have disaggregated information on expenditures on education and health. While spending on tertiary or college education tends to be regressive spending in primary education, especially in rural areas tends to much more progressive; similarly spending on primary health programs is generally expected to be much more progressive than spending on hospitalization programs. But again, unfortunately, internationally comparable disaggregated data on these forms of public spending are not available. For our analysis, therefore we are forced to employ the aggregate categories of expenditures measured as percent of GDP. Even though these variables are subject to observation error-induced by the level of aggregation--, we are hopeful they still can tell an interesting story. We anticipate all four types of expenditures to have a positive effect on income equality.

\section{Control Variables}

To avoid specification biases in our estimates of the impact of tax and spending patterns on income inequality it is important that in the regressions we account for the relevant economic and social determinants of income distribution consistently found in the previous literature on 
income distribution (see Milanovic, 2006; De Gregorio and Lee, 2002; Gupta, Davoodi, \& Alonso-Terme, 2002). These control variables generally consider changes in labor supply, labor demand, and an assortment of institutional changes. For example depending on how welfare and social security programs work, they may adapt to reduce inequalities as the level of unemployment increases, although not enough to offset the decrease in market income for the unemployed. Factors affecting labor supply include population size, age structure, and education attainment. On the labor demand size, important factors include technological change, international trade and outsourcing. Finally, the quality of institutions is very important because it affects the impact of changes in the labor market. For example, high political corruption allows certain interest groups to influence policy-makers to implement policies that do not necessarily benefit low-income groups. In addition, the size of government also matters. Larger governments may be more able to meet the demands of low-income households and individuals through different social programs. More specifically, the control variables we include in the regressions are described in the following paragraphs.

The population growth rate is expected to have positive effect on income inequality as faster growing societies experience faster growing demand for public services and increased difficulties of governments to provide those services; at the same time market earnings are expected to be more diverse. Moreover, faster growing population likely leads to an increase in the ratio of profits and rents to labor earnings. Since income from profits and rents is less equally distributed than labor income (Kuznets, 1963), faster growing population may lead to less equally distributed income (Boulier, 1975).

Income distribution in a country also depends on the age structure. To capture this dimension, previous works on income inequality commonly use two demographic variables: the youth dependency ratio (defined as the ratio of the number of persons ages 0-15 to the number of persons ages 16-64) and the old-age dependency ratio (defined as the ratio of persons ages 65 or over to the number of persons ages 16-64). Higher youth dependency is expected to likely result in higher income inequality, mainly because higher youth dependency suggests higher average number of children per household and lower household per capita income. On the other hand, larger share of elderly in population is expected to be associated with relatively lower income 
inequality. Literature suggests that the effect of old-age dependency ratio on income inequality basically depends on the design of the pension system. In a case when there is no government program, higher ratio of elderly to working population raises income inequality, while in presence of a redistributive tax-transfer scheme and state pensions, aging population decreases inequality (Von Weizsacker, 1989). Having in mind that in most countries elderly represent significant group of voters, it is likely that politicians, whose objective is maximizing number of votes, would implement government programs that would benefit elderly, resulting in lower income inequality.

Another important component of income inequality is level of education of individuals. There is a large literature on the effect of education on income inequality which can be divided into two groups; namely, on the one side are studies that find that more unequal education distribution implies more income inequality (the so-called "composition" effect), and on the other side are studies that find that a higher average education level leads to less income inequality (the "compression" effect) (Knight \& Sabot, 1983). In order to account for this effect, we include a variable measuring the average number of years of schooling in country $i$ in year $t$. Higher level of education is assumed to increase disposable income to households and individuals, and potentially reduce income inequality.

Similarly, higher unemployment rate is associated with many economic changes that have important consequences for income distribution. Literature suggests that higher unemployments increases inequality of income and welfare because unemployment risks are higher among lowincome earners (Bjorklung, 1991). Unemployment reduces the ability of people to earn income and achieve standard of living, potentially leading to higher income inequality. On the other hand, economic development measured by GDP per capita growth rate implies higher disposable income per capita and per household, and may be associated with lower income inequality, although this is not necessarily the case because different inequality patterns can hide behind the same GDP per capita growth ratios .

We also introduce two institutional variables. First, there has been an intense debate in recent years about the effect of globalization on the distribution of income. Studies like WEO (2007) 
find that globalization has been one of the factors that have negatively affected labor income in advanced economies therefore becoming an important factor behind increased inequality. In order to capture this dimension of income inequality, we use the KOF index of globalization (Dreher, 2006; updated Dreher, Noel, and Martens, 2008), which takes values between zero and hundred (higher values denote greater globalization). The globalization index takes into account actual economic flows (e.g. trade, stock of FDI), economic restrictions (e.g. import barriers, tariff rates), data on information flows (e.g. internet users, trade in newspapers), data on personal contact (e.g. telephone traffic, international tourism), and data on cultural proximity.

Second, in order to control for the quality of overall governance and efficiency of the public sector we control for the level of corruption. There have not been many studies on the impact of corruption on income inequality. Those few papers that do investigate this relationship find that corruption increases income inequality, mostly by reducing economic growth (Gupta et al. 2002). We can also reasonably assume that high levels of corruption are correlated with tax evasion, which is more likely to make the true distribution of income more unequal (as in Duncan and Sabirianova Peter, 2008) We measure corruption with the ICRG's assessment of corruption within the political system and it is expected to lead to increased inequality because such corruption distorts the economic and financial environment and affects people's ability to earn income and achieve reasonable standards of living. Finally, we control for the size of government as a proxy for the ability of governments to respond to the demands of lower income households and individuals.

By looking at the impact of all taxes (and not only personal income taxes and social contributions as in Immervoll and Richardson, 2011) and many different categories of expenditures (and not just direct cash transfers to the non elderly as for example in Immervoll and Richardson (2011)), the scope of this study goes beyond what has been done in the previous literature. But what we gain in completeness by looking at all taxes and several expenditures, we lose in detail for being able to identify for example individual cash transfer programs. 


\section{Empirical Findings}

As mentioned above, our empirical analysis consists of three parts. In the first part we focus our analysis only on the tax structure and its effect on income inequality. In the second part our interest is to investigate distributional effect of different types of public expenditures. Finally, in the third part we combine both tax instruments and types of public spending and evaluate their joint effect on income inequality.

\section{Taxation and Income Inequality}

Table 1 below presents the results obtained from estimating model (1) when only tax variables are included in the analysis along with the other control variables. Column (1) presents the benchmark results obtained by including only control variables. Most of the control variables are statistically significant and have the predicted sign as discussed above. First, our results provide support to the hypothesis that demographic changes affect income inequality. Faster growing countries, as expected, seem to experience larger income inequality, which corresponds to the findings in the literature. However, we do not limit our analysis only on observing population growth, but also other aspects of population dynamics. More precisely, we consider the effect of age structure in terms of young- and old-age dependency ratios and provide some support to the hypothesis that these two groups of dependent population have the opposite effect on income inequality. Furthermore, as suggested by the large literature on education and income inequality, higher average education level implies more equal income distribution. Similarly, we provide support to the hypothesis that a higher unemployment rate increases inequality in income distribution. Furthermore, our results on the effect of globalization and corruption are consistent with findings from the literature which suggests that higher globalization and corruption increase income inequality. Finally, we find that countries with larger governments have more equal income distribution, due to their ability to respond better to the needs of the population. Columns (2)-(7) of Table 1 present the results obtained by individually including each alternative tax instruments in equation (1).

As the results in column (2) suggest, PIT has the expected positive effect on income inequality, and this effect increases with more progressive tax structure, even though the economic effect is 
not very large. For example, with zero progressivity of PIT, one percentage point increase in the share of PIT to GDP results in a 0.1 percentage point reduction in income inequality. In addition, one percentage point increase in PIT progressivity increases the negative effect of PIT on income inequality by 0.005 percentage points.

Column (3) presents the results obtained by focusing only on the effect of CIT on income inequality.

Theory on the incidence of social security contributions and payroll taxes suggests that imposing these types of taxes results in a combination of lower real wages and higher unemployment rates. While these taxes are commonly levied equally between employers and employees, there is a broad consensus among economists that they are mostly shifted to employees in form of low wages, ultimately resulting in increased income inequality. Results on column 4 in Table 1 provide support to this hypothesis - an increase of one percentage point in the share of social security taxes leads to an increase in income inequality by 0.7 percentage points.

The common perception regarding the general sales tax-- GST (or VAT)-- is that is regressive because poorer households spend a greater share of their income on consumption, so they are likely to pay higher average tax relative to the higher income households. However, not much empirical work has been done so far testing this general conjecture. The results obtained in column 5 of Table 1 provide support to that hypothesis. Our results suggest that an increase of one percentage point in the share of GST in GDP increases income inequality by around 0.5 percentage points. As we have commented above, all other types of indirect taxes, excises and customs duties may be regressive. Our results in columns 6 and 7 provide only weak support to this hypothesis with estimated coefficient being positive but not statistically significant, probably reflecting the composition of such taxes.

Finally, in column 8 of Table 1 we present the results obtained by estimating model (1) when all tax instruments are included, but still without taking into account public spending. Most of the estimated coefficients keep their expected sign, but some of them lose statistical significance, which may be explained by a significant reduction of the sample size when all tax instruments are included (sample size reduces by 32 percent when all tax instruments are included). In 
particular, the estimated coefficient CIT and the interaction term of CIT and globalization remain statistically significant. The estimated coefficients for PIT and the interaction term of PIT and PIT progressivity are also jointly significant at 5 percent significance level. Moreover, all tax variables are jointly significant at 1 percent significance level.

In summary, the results in Table 1 show --as far as we know for the first time in the literature--, in a rich multi-country panel context the validation of most of the conventional conclusions on the final economic incidence of different taxes, which typically have been applied and tested in the context of static country-case studies. ${ }^{22}$

\footnotetext{
${ }^{22}$ As we have seen some recent papers, such as Duncan and Sabirianova Peter (2008) have examined the impact of a one single tax, the PIT. Our results for progressivity are similar to those they obtain. However, in our regressions we anchor the progressivity index with the relative importance of PIT collections in GDP while Duncan and Sabirianova Peter (2008) do not. But clearly the ability of a highly progressive PIT to redistribute income depends also on the size of its collections relative to GDP.
} 
Table1. Taxation and Income Inequality

\begin{tabular}{|c|c|c|c|c|c|c|c|c|}
\hline & $(1)$ & $(2)$ & (3) & (4) & (5) & $(6)$ & $(7)$ & $(8)$ \\
\hline \multirow[t]{2}{*}{ Gini $_{-1}$} & $-0.061 *$ & $0.019 * * *$ & $-0.069 * * *$ & 0.048 & 0.009 & $-0.156 * * *$ & $-0.066^{*}$ & $0.110 * * *$ \\
\hline & $(0.033)$ & $(0.005)$ & $(0.010)$ & $(0.051)$ & $(0.035)$ & $(0.036)$ & $(0.036)$ & $(0.015)$ \\
\hline \multirow[t]{2}{*}{ Net } & $5.164 * * *$ & $5.281 * * *$ & $4.893 * * *$ & -0.810 & $4.608 * * *$ & $5.170 * * *$ & $4.762 * * *$ & 2.173 \\
\hline & $(1.010)$ & $(0.509)$ & $(0.292)$ & $(4.261)$ & $(0.937)$ & $(1.103)$ & $(1.396)$ & $(2.273)$ \\
\hline \multirow[t]{2}{*}{ Gross } & $5.424 * * *$ & $5.593 * * *$ & $4.179 * * *$ & 0.300 & $4.824 * * *$ & $6.091 * * *$ & $5.159 * * *$ & 3.290 \\
\hline & $(1.236)$ & $(0.508)$ & $(0.343)$ & $(3.799)$ & $(1.179)$ & $(1.469)$ & $(1.677)$ & $(2.409)$ \\
\hline \multirow[t]{2}{*}{ Pop. growth } & $0.593 * * *$ & $0.479 * * *$ & 0.113 & 0.338 & $0.486^{* *}$ & 0.126 & $0.473 * *$ & 0.124 \\
\hline & $(0.203)$ & $(0.126)$ & $(0.205)$ & $(0.259)$ & $(0.192)$ & $(0.290)$ & $(0.192)$ & $(0.316)$ \\
\hline \multirow[t]{2}{*}{ Age Dep. Youth } & $0.122 * * *$ & $-0.040 * *$ & $-0.078 * * *$ & $0.105 * *$ & $0.127 * * *$ & $0.159 * *$ & $0.190 * * *$ & -0.074 \\
\hline & $(0.041)$ & $(0.020)$ & $(0.017)$ & $(0.044)$ & $(0.044)$ & $(0.062)$ & $(0.061)$ & $(0.062)$ \\
\hline \multirow[t]{2}{*}{ Age Dep. Elderly } & $-0.498 * * *$ & -0.028 & $-0.272 * *$ & $-0.621 * * *$ & $-0.404 * * *$ & $-0.363 * * *$ & $-0.706 * * *$ & -0.102 \\
\hline & $(0.128)$ & $(0.079)$ & $(0.138)$ & $(0.178)$ & $(0.124)$ & $(0.140)$ & $(0.138)$ & $(0.160)$ \\
\hline \multirow[t]{2}{*}{ Education } & $-0.787 * * *$ & $-0.390 * * *$ & $-0.244 * * *$ & $-0.559 * * *$ & $-0.782 * * *$ & $-0.462 * *$ & $-0.428 * *$ & $-1.139 * * *$ \\
\hline & $(0.159)$ & $(0.077)$ & $(0.049)$ & $(0.201)$ & $(0.222)$ & $(0.208)$ & $(0.205)$ & $(0.222)$ \\
\hline \multirow[t]{2}{*}{ Unemployment } & $0.133 * * *$ & $0.153 * * *$ & $0.098 * * *$ & $0.105 * * *$ & $0.139 * * *$ & $0.147 * * *$ & $0.130 * * *$ & $0.121^{*}$ \\
\hline & $(0.020)$ & $(0.007)$ & $(0.019)$ & $(0.031)$ & $(0.028)$ & $(0.027)$ & $(0.022)$ & $(0.066)$ \\
\hline \multirow[t]{2}{*}{ GDP pc growth } & 0.011 & $-0.009 * *$ & -0.008 & 0.021 & 0.011 & 0.010 & 0.016 & $-0.042 * *$ \\
\hline & $(0.009)$ & $(0.004)$ & $(0.005)$ & $(0.014)$ & $(0.011)$ & $(0.009)$ & $(0.011)$ & $(0.018)$ \\
\hline \multirow[t]{2}{*}{ Globalization } & $0.113 * * *$ & $0.083 * * *$ & $0.082 * * *$ & $0.080 * * *$ & $0.106 * * *$ & $0.069 * * *$ & $0.089 * * *$ & 0.035 \\
\hline & $(0.017)$ & $(0.011)$ & $(0.022)$ & $(0.024)$ & $(0.015)$ & $(0.021)$ & $(0.019)$ & $(0.028)$ \\
\hline \multirow[t]{2}{*}{ Corruption } & $0.203 * * *$ & $0.173 * * *$ & $0.337 * * *$ & $0.274 * * *$ & $0.233 * * *$ & $0.326 * * *$ & $0.211 * * *$ & 0.009 \\
\hline & $(0.064)$ & $(0.057)$ & $(0.031)$ & $(0.064)$ & $(0.067)$ & $(0.081)$ & $(0.074)$ & $(0.194)$ \\
\hline \multirow[t]{2}{*}{ Total Revenues } & -0.020 & $-0.027 * * *$ & 0.005 & $-0.069 *$ & $-0.059 * * *$ & 0.019 & -0.006 & \\
\hline & $(0.021)$ & $(0.007)$ & $(0.023)$ & $(0.036)$ & $(0.022)$ & $(0.023)$ & $(0.020)$ & \\
\hline \multirow[t]{2}{*}{ PIT } & & $-0.094 * *$ & & & & & & -0.105 \\
\hline & & $(0.043)$ & & & & & & $(0.098)$ \\
\hline \multirow[t]{2}{*}{ PIT*Progressivity } & & $-0.005 * * *$ & & & & & & -0.004 \\
\hline & & $(0.001)$ & & & & & & $(0.003)$ \\
\hline \multirow[t]{2}{*}{ CIT } & & & $-0.703 * * *$ & & & & & $-0.925 * *$ \\
\hline & & & $(0.109)$ & & & & & $(0.397)$ \\
\hline
\end{tabular}


Table1. Taxation and Income Inequality (continued)

\begin{tabular}{|c|c|c|c|c|c|c|c|c|}
\hline & $(1)$ & (2) & (3) & (4) & (5) & (6) & (7) & (8) \\
\hline CIT*Globalization & & & $\begin{array}{c}0.009 * * * \\
(0.002)\end{array}$ & & & & & $\begin{array}{c}0.013 * * \\
(0.006)\end{array}$ \\
\hline SSC+Payroll & & & & $\begin{array}{c}0.720 * * * \\
(0.168)\end{array}$ & & & & $\begin{array}{c}0.234 \\
(0.168)\end{array}$ \\
\hline GST & & & & & $\begin{array}{c}0.485 * * * \\
(0.154)\end{array}$ & & & $\begin{array}{c}0.314 \\
(0.343)\end{array}$ \\
\hline Excise & & & & & & $\begin{array}{c}0.258 \\
(0.195)\end{array}$ & & $\begin{array}{c}0.988 * * * \\
(0.301)\end{array}$ \\
\hline Customs & & & & & & & $\begin{array}{c}0.130 \\
(0.178)\end{array}$ & $\begin{array}{c}-0.497 \\
(0.393)\end{array}$ \\
\hline Constant & $\begin{array}{c}31.400 * * * \\
(3.503)\end{array}$ & $\begin{array}{c}30.658 * * * \\
(1.848)\end{array}$ & $\begin{array}{c}38.326^{* * *} \\
(1.917)\end{array}$ & $\begin{array}{c}39.337 * * * \\
(5.696)\end{array}$ & $\begin{array}{c}32.397 * * * \\
(3.994)\end{array}$ & $\begin{array}{c}35.120 * * * \\
(4.698)\end{array}$ & $\begin{array}{c}30.118^{* * * *} \\
(4.372)\end{array}$ & $\begin{array}{c}35.716^{* * *} * \\
(3.720)\end{array}$ \\
\hline Observations & 936 & 713 & 834 & 873 & 908 & 834 & 871 & 634 \\
\hline Number of id & 79 & 69 & 75 & 74 & 78 & 71 & 75 & 56 \\
\hline Sargan & 42.92 & 58.41 & 66.80 & 37.12 & 35.21 & 35.74 & 39.58 & 37.69 \\
\hline AR2 & 0.866 & 0.857 & 0.727 & 0.950 & 0.798 & 0.960 & 0.992 & 1.153 \\
\hline
\end{tabular}




\section{Public Spending and Income Inequality}

We turn now to the results obtained on the effect of public spending on income inequality. As we already explained above, we focus on four types of social spending; namely, social protection expenditures, expenditures on education, health, and housing. As in case of taxation, here also we first estimate the model (1) by introducing separately types of expenditures, and then we estimate the model by including all four expenditure categories. It is important to point out that internationally comparable data on functional classification of expenditures is very scarce, which has an effect on our results, especially when all expenditure categories are included in the model. Including only social protection expenditures in the model results in a reduction of sample size by 35 percent. Column 2 in Table 2 shows the results obtained by estimating this regression. Our results suggest that one percentage point increase in expenditures for social protection reduces income inequality by 0.14 percentage points. Similar effect is estimated for expenditures on education in column 3. Estimated effects of expenditures on health and household are a bit higher - one percentage point in these two types of expenditures leads to a reduction in income inequality by between 0.7 and 0.8 percentage points. Finally, when all four expenditure components are included in the model, all but education keep their expected sign, with only expenditure on health remaining statistically significant. This loss in significance could be very well contributed to a significant reduction (56 percent) in sample size. But note that all four categories of expenditures in column 6 of Table 2 are jointly significant at the 1 percent significance level.

In summary, in spite of the high level of aggregation with which we measure the four categories of "redistributional expenditures" we find in agreement with the previous literature that, overall, they contribute to reduce income inequality. Also note that in general, as has been previously found in country-case studies, dollar per dollar fiscal tools in the expenditure side of the budget tend to be more effective than redistributive measures in the revenue side of the budget. For example, using personal income tax to redistribute income would result in lower reduction in income inequality than relying on any type observed social expenditures On the other hand, corporate income tax shows to be close to an equally effective tool of income inequality reduction as some forms of government spending. However, using heavily corporate income tax as a tool of income redistribution has a drawback because as soon as capital is able to leave the 
country and avoid taxation, the burden of corporate income tax falls on labor leading to the opposite than planned effect of such a policy.

A third option would be to reduce taxation on consumption. However, consumption taxes constitute a very important component of government revenues, especially in developing countries where the formal tax base is not well established and using indirect taxes is very important for collecting sufficient amount of government revenues. On the other hand, using any type of observed social expenditures shows to be effective in the reduction of income inequality. For example revenue neutral combination of one percentage point increase in the collection of general sales tax to GDP and equal increase in housing expenditures would result in a reduction of income inequality of 0.3 percentage points. 
Table2. Expenditures and Income Inequality

\begin{tabular}{|c|c|c|c|c|c|c|}
\hline & $(1)$ & $(2)$ & $(3)$ & $(4)$ & $(5)$ & $(6)$ \\
\hline \multirow[t]{2}{*}{ Gini $_{-1}$} & $-0.061 *$ & $-0.066 * * *$ & $-0.152 * * *$ & $-0.088 * * *$ & $-0.197 * * *$ & $-0.097 * *$ \\
\hline & $(0.033)$ & $(0.009)$ & $(0.011)$ & $(0.006)$ & $(0.016)$ & $(0.040)$ \\
\hline \multirow[t]{2}{*}{ Net } & $5.164 * * *$ & $5.748 * * *$ & $4.672 * * *$ & $5.140 * * *$ & $5.379 * * *$ & $5.951 * * *$ \\
\hline & $(1.010)$ & $(1.189)$ & $(0.524)$ & $(0.395)$ & $(0.394)$ & $(1.224)$ \\
\hline \multirow[t]{2}{*}{ Gross } & $5.424 * * *$ & $4.783 * * *$ & $2.987 * * *$ & $3.762 * * *$ & $3.977 * * *$ & $3.499 *$ \\
\hline & $(1.236)$ & $(1.219)$ & $(0.833)$ & $(0.687)$ & $(0.496)$ & $(1.951)$ \\
\hline \multirow[t]{2}{*}{ Pop. growth } & $0.593 * * *$ & $0.726 * * *$ & $0.239 * * *$ & $0.334 * * *$ & $1.160 * * *$ & $1.489 * * *$ \\
\hline & $(0.203)$ & $(0.254)$ & $(0.091)$ & $(0.074)$ & $(0.254)$ & $(0.554)$ \\
\hline \multirow[t]{2}{*}{ Age Dep. Youth } & $0.122 * * *$ & $-0.046 * * *$ & $-0.076 * * *$ & -0.009 & $0.184 * * *$ & $0.203 * *$ \\
\hline & $(0.041)$ & $(0.018)$ & $(0.027)$ & $(0.015)$ & $(0.025)$ & $(0.086)$ \\
\hline \multirow[t]{2}{*}{ Age Dep. Elderly } & $-0.498 * * *$ & -0.118 & $-0.315 * * *$ & $-0.257 * * *$ & -0.324 & $-0.449 * *$ \\
\hline & $(0.128)$ & $(0.110)$ & $(0.070)$ & $(0.066)$ & $(0.217)$ & $(0.192)$ \\
\hline \multirow[t]{2}{*}{ Education } & $-0.787 * * *$ & 0.027 & -0.014 & $-0.167 * *$ & $-0.417 * * *$ & -0.142 \\
\hline & $(0.159)$ & $(0.047)$ & $(0.078)$ & $(0.069)$ & $(0.093)$ & $(0.191)$ \\
\hline \multirow[t]{2}{*}{ Unemployment } & $0.133 * * *$ & $0.119 * * *$ & $0.097 * * *$ & $0.062 * * *$ & $0.112 * * *$ & $0.188 * * *$ \\
\hline & $(0.020)$ & $(0.013)$ & $(0.011)$ & $(0.007)$ & $(0.012)$ & $(0.032)$ \\
\hline \multirow[t]{2}{*}{ GDP pc growth } & 0.011 & $-0.007^{*}$ & 0.003 & $-0.022 * * *$ & -0.006 & 0.008 \\
\hline & $(0.009)$ & $(0.004)$ & $(0.007)$ & $(0.004)$ & $(0.005)$ & $(0.008)$ \\
\hline \multirow[t]{2}{*}{ Globalization } & $0.113 * * *$ & $0.090 * * *$ & $0.120 * * *$ & $0.164 * * *$ & $0.260 * * *$ & $0.213 * * *$ \\
\hline & $(0.017)$ & $(0.014)$ & $(0.014)$ & $(0.010)$ & $(0.016)$ & $(0.023)$ \\
\hline \multirow[t]{2}{*}{ Corruption } & $0.203 * * *$ & $0.415 * * *$ & $0.392 * * *$ & $0.369 * * *$ & $0.169 * * *$ & 0.163 \\
\hline & $(0.064)$ & $(0.030)$ & $(0.029)$ & $(0.015)$ & $(0.027)$ & $(0.134)$ \\
\hline \multirow[t]{2}{*}{ Total Revenues } & -0.020 & $-0.063 * * *$ & $-0.085 * * *$ & $-0.040 * * *$ & -0.002 & \\
\hline & $(0.021)$ & $(0.017)$ & $(0.016)$ & $(0.007)$ & $(0.013)$ & \\
\hline Social & & $-0.139 * * *$ & & & & -0.123 \\
\hline \multicolumn{7}{|l|}{ Protection } \\
\hline & & $(0.038)$ & & & & $(0.097)$ \\
\hline \multirow[t]{2}{*}{ Education } & & & $-0.134 * *$ & & & 0.038 \\
\hline & & & $(0.058)$ & & & $(0.175)$ \\
\hline \multirow[t]{2}{*}{ Health } & & & & $-0.695 * * *$ & & $-0.415^{*}$ \\
\hline & & & & $(0.030)$ & & $(0.230)$ \\
\hline \multirow[t]{2}{*}{ Housing } & & & & & $-0.768 * * *$ & -0.139 \\
\hline & & & & & $(0.068)$ & $(0.168)$ \\
\hline \multirow[t]{2}{*}{ Constant } & $31.400 * * *$ & $33.828 * * *$ & $42.334 * * *$ & $35.543 * * *$ & $24.468 * * *$ & $21.441 * *$ \\
\hline & $(3.503)$ & $(1.923)$ & $(1.755)$ & $(1.525)$ & $(4.247)$ & $(9.714)$ \\
\hline Observations & 936 & 604 & 643 & 694 & 503 & 410 \\
\hline Number of id & 79 & 65 & 67 & 72 & 61 & 54 \\
\hline Sargan & 42.92 & 51.23 & 55.81 & 55.92 & 48.34 & 41.62 \\
\hline AR2 & 0.866 & 0.988 & 0.746 & 0.816 & 0.650 & 1.071 \\
\hline
\end{tabular}

Standard errors in parentheses, ${ }^{* * *} \mathrm{p}<0.01,{ }^{* *} \mathrm{p}<0.05,{ }^{*} \mathrm{p}<0.1$ 


\section{Taxation and Public Spending and Income Inequality}

Finally, table 3 presents results obtained by including all tax and expenditures categories in the sample. Dues to a significant reduction in sample size (68 percent) due to missing values, most of variables in the model lose their statistical significance. Among tax instruments, only PIT and excise taxes keep their expected signs, with this latter being statistically significant only at the 10 percent level. On the expenditure side, estimated coefficients on expenditures on social protection and health keep their negative signs, but only social protection expenditures is statistically significant at the 10 percent level. The lack of degrees of freedom and the generally weak results in Table 3 prevent us from examining the question of whether fiscal redistribution tools on the revenue and expenditure sides of the budget tend to work as complements or substitutes, although the weak results point toward complementarity. This is a question that awaits a more complete panel data set. 
Table3. Taxation, Expenditures and Income Inequality

\begin{tabular}{|c|c|c|c|c|}
\hline & $(1)$ & $(2)$ & $(3)$ & $(4)$ \\
\hline \multirow[t]{2}{*}{ Gini $_{-1}$} & $-0.061 *$ & $0.110 * * *$ & $-0.097 * *$ & -0.026 \\
\hline & $(0.033)$ & $(0.015)$ & $(0.040)$ & $(0.044)$ \\
\hline \multirow[t]{2}{*}{ Net } & $5.164 * * *$ & 2.173 & $5.951 * * *$ & $10.902 * * *$ \\
\hline & $(1.010)$ & $(2.273)$ & $(1.224)$ & $(3.780)$ \\
\hline \multirow[t]{2}{*}{ Gross } & $5.424 * * *$ & 3.290 & $3.499 *$ & $10.429 * *$ \\
\hline & $(1.236)$ & $(2.409)$ & $(1.951)$ & $(4.419)$ \\
\hline \multirow[t]{2}{*}{ Pop. growth } & $0.593 * * *$ & 0.124 & $1.489 * * *$ & $3.098 * * *$ \\
\hline & $(0.203)$ & $(0.316)$ & $(0.554)$ & $(1.087)$ \\
\hline \multirow[t]{2}{*}{ Age Dep. Youth } & $0.122 * * *$ & -0.074 & $0.203 * *$ & -0.347 \\
\hline & $(0.041)$ & $(0.062)$ & $(0.086)$ & $(0.423)$ \\
\hline \multirow[t]{2}{*}{ Age Dep. Elderly } & $-0.498 * * *$ & -0.102 & $-0.449 * *$ & 0.169 \\
\hline & $(0.128)$ & $(0.160)$ & $(0.192)$ & $(1.021)$ \\
\hline \multirow[t]{2}{*}{ Education } & $-0.787 * * *$ & $-1.139 * * *$ & -0.142 & -0.295 \\
\hline & $(0.159)$ & $(0.222)$ & $(0.191)$ & $(0.550)$ \\
\hline \multirow[t]{2}{*}{ Unemployment } & $0.133 * * *$ & $0.121 *$ & $0.188 * * *$ & 0.173 \\
\hline & $(0.020)$ & $(0.066)$ & $(0.032)$ & $(0.141)$ \\
\hline \multirow[t]{2}{*}{ GDP pc growth } & 0.011 & $-0.042 * *$ & 0.008 & -0.070 \\
\hline & $(0.009)$ & $(0.018)$ & $(0.008)$ & $(0.052)$ \\
\hline \multirow[t]{2}{*}{ Globalization } & $0.113 * * *$ & 0.035 & $0.213 * * *$ & 0.224 \\
\hline & $(0.017)$ & $(0.028)$ & $(0.023)$ & $(0.217)$ \\
\hline \multirow[t]{2}{*}{ Corruption } & $0.203 * * *$ & 0.009 & 0.163 & 0.264 \\
\hline & $(0.064)$ & $(0.194)$ & $(0.134)$ & $(0.826)$ \\
\hline \multirow[t]{2}{*}{ PIT } & & -0.105 & & -0.176 \\
\hline & & $(0.098)$ & & $(0.690)$ \\
\hline \multirow[t]{2}{*}{ PIT*Progressivity } & & -0.004 & & -0.013 \\
\hline & & $(0.003)$ & & $(0.021)$ \\
\hline \multirow[t]{2}{*}{ CIT } & & $-0.925 * *$ & & 4.638 \\
\hline & & $(0.397)$ & & $(5.703)$ \\
\hline \multirow[t]{2}{*}{ CIT $^{*}$ Globalization } & & $0.013 * *$ & & -0.065 \\
\hline & & $(0.006)$ & & $(0.074)$ \\
\hline \multirow[t]{2}{*}{ SSC+Payroll } & & 0.234 & & -0.300 \\
\hline & & $(0.168)$ & & $(0.373)$ \\
\hline \multirow[t]{2}{*}{ GST } & & 0.314 & & -0.260 \\
\hline & & $(0.343)$ & & $(0.394)$ \\
\hline \multirow[t]{2}{*}{ Excise } & & $0.988 * * *$ & & $3.148 * *$ \\
\hline & & $(0.301)$ & & $(1.323)$ \\
\hline \multirow[t]{2}{*}{ Customs } & & -0.497 & & -0.762 \\
\hline & & $(0.393)$ & & $(1.592)$ \\
\hline \multirow[t]{2}{*}{ Social Protection } & & & -0.123 & $-0.366^{*}$ \\
\hline & & & $(0.097)$ & $(0.210)$ \\
\hline \multirow[t]{2}{*}{ Education } & & & 0.038 & 0.506 \\
\hline & & & $(0.175)$ & $(0.581)$ \\
\hline
\end{tabular}


Table3. Taxation, Expenditures and Income Inequality (continued)

\begin{tabular}{lcccc}
\hline & $(1)$ & $(2)$ & $(3)$ & $(4)$ \\
\hline Health & & & $-0.415^{*}$ & -0.664 \\
& & & $(0.230)$ & $(0.528)$ \\
Housing & & -0.139 & 0.620 \\
& & & $(0.168)$ & $(0.883)$ \\
Constant & $31.400^{* * *}$ & $35.716^{* * *}$ & $21.441^{* *}$ & 17.770 \\
& $(3.503)$ & $(3.720)$ & $(9.714)$ & $(42.834)$ \\
Observations & 936 & 634 & 410 & 298 \\
Number of id & 79 & 56 & 54 & 42 \\
Sargan & 42.92 & 37.69 & 41.62 & 19.91 \\
AR2 & 0.866 & 1.153 & 1.071 & 0.929 \\
\hline Standard errors in parentheses, *** $<<0.01, * * p<0.05,{ }^{*} p<0.1$ & & &
\end{tabular}

\section{Conclusion}

In this paper we have examined the impact of taxes and some types of public expenditures on income distribution using a large panel data set of 150 countries over a period of over a quarter century (1970-2006). In our empirical analysis, we find significant effects of both taxes and public spending on the Gini coefficient. On the taxation side, our results generally support the findings in previous individual country incidence analysis studies. Progressive personal income taxes have a positive impact on income distribution, contributing to decreasing inequality, and this effect is more pronounced the higher the degree of progressivity and the higher the share of GDP that is collected with the individual income taxes. Corporate income taxes also have a positive effect on income distribution but this effect is eroded away with the degree of globalization or openness. General consumption taxes, excise taxes, and customs duties have a negative impact on income distribution. On the expenditure side, we find that higher shares of GDP on social welfare, education, health, and housing public expenditures have a positive impact on income distribution, individually and collectively.

In terms of the magnitude of the impact of these fiscal policy instruments, both taxes and expenditures, on income distribution, it is estimated as a combination of the estimated marginal effects of each fiscal instrument and the actual change in policy in the use of that fiscal instrument. Thus, even though a particular instrument may be relatively ineffective-having a relatively small marginal impact - this may be more than offset by a large change in the use of 
that instrument, and vice versa. Table 4 summarizes the final effects for each fiscal instrument taking into account our best estimates of the marginal effects (in Tables 1 and 2) and allowing a change in the usage of the instruments that is equal to the overall change between 1990 and 2005. The results are clearly general averages for a large number of countries and for a long period of time. However, we believe they are good summary indicators of the overall effects of fiscal policies on income distribution trends worldwide.

Table 4. Economic Effect of Tax and Expenditure Policy

\begin{tabular}{|c|c|c|c|}
\hline Policy Instrument & $\begin{array}{c}\text { Estimated } \\
\text { Marginal Effect }\end{array}$ & $\begin{array}{l}\text { Increase }(+) / \text { Reduction }(-) \\
\text { between } 1990 \text { and } 2005 \\
\text { (percentage points) }\end{array}$ & $\begin{array}{c}\text { Resulting increase } \\
(+) / \text { reduction }(-) \text { in } \\
\text { income inequality, } \\
\text { ceteris paribus } \\
\text { (percentage points) }\end{array}$ \\
\hline Personal Income Tax & -0.09 & -0.61 & \multirow[b]{2}{*}{0.04} \\
\hline $\begin{array}{l}\text { Personal Income Tax } \\
\text { * Progressivity }\end{array}$ & -0.01 & 1.76 & \\
\hline Corporate Income Tax & -0.70 & 0.24 & \multirow[b]{2}{*}{-0.13} \\
\hline $\begin{array}{l}\text { Corporate Income Tax } \\
* \text { Globalization }\end{array}$ & 0.01 & 3.84 & \\
\hline $\begin{array}{l}\text { Social Security and } \\
\text { Payroll Taxes }\end{array}$ & 0.72 & 0.98 & 0.70 \\
\hline $\begin{array}{l}\text { Taxes on Goods and } \\
\text { Services }\end{array}$ & 0.49 & 2.10 & 1.03 \\
\hline Excises & 0.26 & -0.09 & -0.02 \\
\hline Customs Duties & 0.13 & -0.66 & -0.09 \\
\hline $\begin{array}{l}\text { Total Effect of } \\
\text { Taxes }\end{array}$ & & & 1.53 \\
\hline $\begin{array}{l}\text { Social Protection } \\
\text { Expenditures }\end{array}$ & -0.14 & 1.57 & -0.22 \\
\hline $\begin{array}{l}\text { Education } \\
\text { Expenditures }\end{array}$ & -0.13 & -0.86 & 0.12 \\
\hline Health Expenditures & -0.70 & 2.11 & -1.46 \\
\hline Housing Expenditures & -0.77 & -0.78 & 0.60 \\
\hline $\begin{array}{l}\text { Total Effect of } \\
\text { Expenditures }\end{array}$ & & & $\mathbf{- 0 . 9 7}$ \\
\hline
\end{tabular}

Note: All instruments expressed as \% of GDP

Despite the fact that personal income taxes are progressive, the significant decreases in personal income tax collections as \% of GDP accompanied by the overall reduction in the index of 
progressivity of these taxes led to a relatively minor increase in overall income inequality of 0.04 in the Gini coefficient.

On the other hand, corporate income taxes, which also result as being generally progressive, increased in size and, despite the increase in overall globalization -which tends to decrease the progressivity of this tax-, the overall result was a contribution to reducing income inequality by 0.13 of the Gini coefficient.

The significant increases in the sizes of social security contributions and payroll taxes, and general consumption taxes - both being generally regressive-- led to much larger increases in income inequality, of 0.70 and 1.03 of the Gini coefficient, respectively.

For excises and customs duties - both also generally regressive - their decrease in size as share of GDP from 1990 to 2005 led to decreases in income inequality of 0.02 and 0.09 of the Gini coefficient, respectively.

On the expenditure side, the four categories of public expenditures considered, social protection, education, health, and housing, appear all as being progressive but their impact has been different depending on how their share if GDP has changed over the 1990-2005 period. The increases in social protection expenditures led to a reduction of the Gini of 0.22 and the increases in public health expenditures also led to a decrease in inequality, in this case significantly larger of 1.46 of the Gini. The reductions in public expenditures in education and housing shares led to increases in inequality of 0.12 and 0.60 of the Gini, respectively.

From a policy perspective, we can observe that taxes and public expenditures policies cannot be identified as strictly substitute or complementary instruments toward redistribution goals. ${ }^{23}$ For both taxes and expenditures the use of instruments was mixed; some contributed to decreasing inequality and some had the opposite effect.

\footnotetext{
${ }^{23}$ This question has been addressed by Bahl et al. (2002) at the state level in the United States.
} 
Similarly, our results would not lead us to conclude that expenditure policies have been more effective overall than taxes in affecting income distribution, although this result needs to be interpreted with caution because only a few public spending categories have been selected. And finally, also from the perspective of a policy maker, it is clear that the overall impact of fiscal policy as a whole has been quite limited. Over the 1990-2005 period, the net effect of tax policies was to increase inequality by 1.53 of the Gini while the impact of expenditure policies was to decrease inequality by 0.97 of the Gini.

Of course, we must be mindful that income redistribution is not the only objective of fiscal policy design. Besides collecting revenues, tax and expenditure policies have an impact on macroeconomic stability as well as the efficient allocation of resources and economic growth. Even beyond that, in a globalize world, fiscal policy affects the overall competitiveness of a country, attracting or discouraging foreign investors. However, based on our results, its potential to drastically affect the Gini coefficient and change income distribution patterns should not be overestimated. 


\section{References}

Adam, S. and J. Browne (2010), "Redistribution, Work Incentives and Thirty Years of UK Tax and Benefit Reform", IFS Working Paper No. 10/24, Institute for Fiscal Studies, London.

Afonso, A., Ebert, W., Schuknecht, L., \& Thone, M. (2005). Quality of public finances and growth. European Central Bank, Working Paper Series: 438.

Alfranca, O., \& Galindo, M.-A. (2003). Public Expenditure, Income Distribution, and Growth in OECD Countries. International Advances in Economic Research, 9(2), 133-139.

Anand, S., \& Kanbur, S. M. R. (1993). The Kuznets Process and the Inequality-Development Relatioship. Journal of Development Economics, 40, 25-52.

Angelopoulos, K., Philippopoulos, A., \& Tsionas, E. (2008). Does Public Sector Efficiency Matter? Revisiting the Relation between Fiscal Size and Economic Growth in a World Sample. Public Choice, 137(1-2), 245-278.

Araujo, M. C., Ferreira, F. H. G., Lanjouw, P., \& Ozler, B. (2008). Local Inequality and Project Choice: Theory and Evidence from Ecuador. Journal of Public Economics, 92(5-6), 1022-1046.

Arellano, M., and Bond, S. (1991). Some tests of specification for panel data: Monte Carlo evidence and an application to employment equations. The Review of Economic Studies, 58(2), 277-297.

Arellano, M., and Bover, O. (1995). Another look at the instrumental variable estimation of error-components models. Journal of Econometrics, 68(1), 29-51.

Baer, W., \& Galvao, A. F., Jr. (2008). Tax Burden, Government Expenditures and Income Distribution in Brazil. Quarterly Review of Economics and Finance, 48(2), 345-358.

Bahl, Roy and Jorge Martinez-Vazquez and Sally Wallace. 2002. State and Local Government Choices in Fiscal Redistribution. National Tax Journal 60(4) 723-742.

Bayraktar, N., \& Moreno-Dodson, B. (2010). How can public spending help you grow ? an empirical analysis for developing countries. The World Bank, Policy Research Working Paper Series: 5367.

Bird, R.M., \& Zolt, E.M. (2005). Redistribution via Taxation: The Limited Role of the Personal Income Tax in Developing Countries. UCLA Law Review 52(6), 1627-95

Bjorklund, A. (1991). Unemployment and Income Distribution: Time-Series Evidence from Sweden. Scandinavian Journal of Economics, 93(3), 457.

Blundell, R., and Bond, S. (1998). Initial conditions and moment restrictions in dynamic panel data models. Journal of econometrics, 87(1), 115-143.

Borge, L.-E., \& Rattso, J. (2004). Income distribution and tax structure: Empirical test of the Meltzer-Richard hypothesis. European Economic Review 48, 805-826.

Boulier, B. (1975). The effects of demographic variables on income distribution. Woodrow Wilson School Discussion Paper No. 6. Princeton, N.J.: Princeton University.

Boustan, L. P., Ferreira, F., Winkler, H., \& Zolt, E. (2010). Income Inequality and Local Government in the United States, 1970-2000. National Bureau of Economic Research, Inc, NBER Working Papers: 16299.

Caminada, K., \& Goudswaard, K. (2001). International Trends in Income Inequality and Social Policy. International Tax and Public Finance, 8(4), 395-415.

Campiglio, L. (1990). Income Distribution, Public Expenditure and Equality. Labour, 4(1), 97124. 
Chen, B.-L. (2006). Economic Growth with an Optimal Public Spending Composition. Oxford Economic Papers, 58(1), 123-136.

Clarke, G. R. G. (1992). More Evidence on Income Distribution and Growth, Policy Research Working Paper 1064. Washington DC: The World Bank.

Clements, B. (1997). Income Distribution and Social Expenditure in Brazil. International Monetary Fund, IMF Working Papers: 97/120.

Day, R. H., \& Yang, C. (2011). Economic Growth and the Effects of Fiscal Policy. Metroeconomica, 62(1), 218-234.

De Mello, L., \& Tiongson, E. (2006). Income Inequality and Redistributive Government Spending. Public Finance Review, 34(3), 282-305.

Dollar, D., \& Kraay, A. (2002). Growth is Good for the Poor. Journal of Economic Growth, 7(3), 195-225.

Dreher, Axel (2006): Does Globalization Affect Growth? Evidence from a new Index of Globalization, Applied Economics 38, 10: 1091-1110.

Dreher, Axel, Noel Gaston and Pim Martens (2008), Measuring Globalisation - Gauging its Consequences (New York: Springer).

Duncan, D. and K. Sabirianova Peter. (2008). "Tax Progressivity and Income Inequality." Georgia State University Andrew Young School of Policy Studies Working Paper 08-26.

Glennerster, H., (2006), "Tibor Barna: The redistributive impact of taxes and social policies in the UK: 1937-2005”, CASE LSE STICERD Research Paper No. CASE115, London School of Economics.

Gravelle, J. (1992) Journal of Economic Perspectives

Gregorio, J. D., \& Lee, J. (2002). Education and Income Inequality: New Evidence From CrossCountry Data. Review of Income \& Wealth, 48(3), 395-416.

Gupta, S., Davoodi, H., \& Rosa Alonso-Terme (2002). "Does Corruption Affect Income inequality and Poverty?" Economics of Governance 3: 23-45.

Guran, M. C., \& Tosun, M. U. (2008). A Cross-Country Analysis of Public Sector Interventions' Efficiency. Ekonomicky Casopis/Journal of Economics, 56(2), 182-211.

Harberger, A. C. (1995). The ABCs of Corporation Tax Incidence: Insights into the Open Economy Case. Tax Policy and Economic Growth, Washington D.C.: American Council for Capital Formation.

Harberger, A. C. 1962. "The Incidence of the Corporate Income Tax." Journal of Political Economy 70: 215-240. June.

Harberger, A.C. (1998). "A Vision of the Growth process," The American Economic Review, 88(1): 1-32.

Harberger, A.C. (2006). Taxation and Income Distribution: Myths and Realities. In J. Alm, J. Martinez-Vazquez and M. Rider, eds., The Challenges of Tax Reform in a Global Economy (New York: Springer)

Herrera, S. (2007). Public expenditure and growth. The World Bank, Policy Research Working Paper Series: 4372.

Holtz-Eakin, D., Newey, W., and Rosen, H. (1988). Estimating vector autoregressions with panel data. Econometrica: Journal of the Econometric Society, 56(6), 1371-1395.

Immervoll, H. and L. Richardson. (2011). Redistribution Policy and Inequality Reduction in OECD Countries: What Has Changed in Two Decades? Institute for the Study of Labor IZA Dicussion Paper No. 6030.(October) 
Immervoll, H., Levy, H., C. Lietz, D. Mantovani, C. O., Donoghue, H. Sutherland \& Verbist, G. (2006), "Household Incomes and Redistribution in the European Union: Quantifying the Equalising Properties of Taxes and Benefits", in: D B Papadimitriou (ed.), The Distributional Effects of Government Spending and Taxation, Palgrave Macmillan.

Jao, C.-C. (2000). The Impact of Tax Revenue and Social Welfare Expenditure on Income Distribution in Taiwan. Journal of the Asia Pacific Economy, 5(1-2), 73-90.

Keuning, S., \& Thorbecke, E. (1989). The Impact of Budget Retrenchment on Income Distribution in Indonesia (including Statistical Annex): A Social Accounting Matrix Application. OECD Development Centre, OECD Development Centre Working Papers: 3.

Khemani, S. (2010). Political economy of infrastructure spending in India. The World Bank, Policy Research Working Paper Series: 5423.

Knight, J. B., \& Sabot, R. H. (1983). Educational Expansion and the Kuznets Effect. American Economic Review 73(5), 1132-1136.

Kuznets, S. (1955). Economic Growth and Income Inequality. The American Economic Review, 45(1), 1-28.

Li, W., \& Sarte, P.-D. (2004). Progressive taxation and long-run growth. American Economic Review 94(5), 1705-1716.

Martinez-Vazquez, J. (2008). The Impact of Budgets on the Poor: Tax and Expenditure Benefit Incidence Analysis", in Public Finance for Poverty Reduction, Blanca Moreno-Dodson and Quentin Wodon (eds.) World Bank.

Milanovic, B. (2006). Global income inequality : what it is and why it matters. The World Bank Policy Research Working Paper Series, WPS3865.

Moreno-Dodson, B. (2008). Assessing the impact of public spending on growth - an empirical analysis for seven fast growing countries. The World Bank, Policy Research Working Paper Series: 4663.

Meltzer, A. H., and S. F. Richard (1981). A Rational Theory of the Size of Government. The Journal of Political Economy 89(5), 914-927.

Musgrave Richard and Tun Thin, 1948. Income Tax Progression, 1929-48. Journal of Political Economy 56(6): 498-514.

Ocampo, J. A. (1998). Income Distribution, Poverty and Social Expenditure in Latin America. CEPAL Review (65), 7-14.

Ozsoy, O. (2008). Government Budget Deficits, Defence Expenditure and Income Distribution: The Case of Turkey. Defence and Peace Economics, 19(1), 61-75.

Paternostro, S., Rajaram, A., \& Tiongson, E. R. (2007). How Does the Composition of Public Spending Matter? Oxford Development Studies, 35(1), 47-82.

Persson, T. and G. Tabellini, 1999. "Political Economics and Public Finance," NBER Working Paper, No. 7097.

Peter, K. S., Buttrick, S., \& Duncan, D. (2010). Global Reform of Personal Income Taxation, 1981-2005: Evidence from 189 Countries. National Tax Journal, 6(3), 447-478.

Riihelä, M., R. Sullström and I. Suoniemi (2008), "Tax progressivity and recent evolution of the Finnish income inequality”, VATT Discussion Paper No. 460, VATT Government Institute for Economic Research, Helsinki.

Roodman, D. (2006). How to do xtabond2: An introduction to difference and system GMM in Stata. Center for Global Development Working Paper Number 103. 
Samanta, S. K., \& Cerf, J. G. (2009). Income Distribution and the Effectiveness of Fiscal Policy: Evidence from Some Transitional Economies. East-West Journal of Economics and Business, 12(1), 29-45.

Sawers, L., \& Wachtel, H. M. (1975). Theory of the State, Government Tax and Purchasing Policy, and Income Distribution. Review of Income \& Wealth, 21(1), 111-124.

Schaltegger, C. A., \& Torgler, B. (2006). Growth Effects of Public Expenditure on the State and Local Level: Evidence from a Sample of Rich Governments. Applied Economics, 38(10), 1181-1192.

Schuknecht, L., \& Tanzi, V. (2005). Reforming public expenditure in industrialised countries are there trade-offs? European Central Bank, Working Paper Series: 435.

Schwartz, G., \& Ter-Minassian, T. (2000). The Distributional Effects of Public Expenditure. Journal of Economic Surveys, 14(3), 337-358.

Sepulveda, C., \& Martinez-Vazquez, J. (2010). The Consequences of Fiscal Decentralization on Poverty and Income Inequality. International Studies Program, Andrew Young School of Policy Studies, Georgia State University, International Studies Program Working Paper Series, at AYSPS, GSU.

Smeeding, T. M. (2004). Twenty Years of Research on Income Inequality, Poverty and Redistribution in the Developed World: Introduction and Overview". Socio-Economic Review, 2(149-163).

Strulik, H. (2007). A Distributional Theory of Government Growth. Public Choice, 132(3-4), 305-318.

Tiongson, E. R., Rajaram, A., \& Paternostro, S. (2005). How does the composition of public spending matter? The World Bank, Policy Research Working Paper Series: 3555.

Varoudakis, A., Tiongson, E. R., \& Pushak, T. (2007). Public finance, governance, and growth in transition economies: empirical evidence from 1992-2004. The World Bank, Policy Research Working Paper Series: 4255.

Von Weizsacker, R. K. (1989). Demographic change and income distribution. European Economic Review, 33(2-3), 377-388.

Wagstaff A. and E. van Doorslaer, 2001, "What Makes the Personal Income Tax Progressive? A Comparative Analysis for Fifteen OECD Countries", International Tax and Public Finance, 8(3), 299-316.

Wagstaff A. and 24 other authors ,1999, "Redistributive effect, progressivity and differential tax treatment: Personal income taxes in twelve OECD countries", Journal of Public Economics, 72, 73-98.

Weller, C. E. (2007). The Benefits of Progressive Taxation in Economic Development. Review of Radical Political Economics 39(3), 368-376.

Zou, H.-f., Swaroop, V., \& Devarajan, S. (1993). What do governments buy? The composition of public spending and economic performance. The World Bank, Policy Research Working Paper Series: 1082. 